\title{
Marta Duch-Dyngosz
}

Institut für Europäische Ethnologie, Center for Anthropological Research on Museums and Heritage, Humboldt-Universität https://orcid.org/0000-0002-9469-5901 marta.duch@uj.edu.pl

\section{W poszukiwaniu lokalnej pamięci o Zagładzie. Przypadek upamiętniania społeczności żydowskich w mniejszych miejscowościach we współczesnej Polsce}

\begin{abstract}
Streszczenie
W artykule poddałam analizie strategie obrazowania Zagłady w inicjatywach upamiętniających społeczności żydowskie w lokalnej Polsce. Zagłada Żydów jest przykładem trudnej pamięci, która podważa grupowe wartości i normy społeczne, co w przypadku lokalnych społeczności wiąże się z doświadczeniami „bycia blisko Zagłady”. Pozycja względem cierpienia społeczności żydowskiej stała się punktem wyjścia zróżnicowanych postaw (współ)odpowiedzialności i (współ)uczestnictwa członków lokalnych społeczności w zagładzie Żydów. Często pamięć o tych wydarzeniach pozostawała przedmiotem lokalnego przekazu potocznego po wojnie. W związku z tym w powojennych miejscowościach, do Zagłady zamieszkiwanych przez liczne społeczności żydowskie, uformowały się specyficzne wspólnoty pamięci charakteryzujące się zmową milczenia dotyczącą lokalnej historii i kultury żydowskiej. W ostatnim czasie w tak ukształtowanych przestrzeniach społecznych można zaobserwować coraz więcej inicjatyw upamiętniających, które przywołują różne aspekty lokalnego dziedzictwa żydowskiego. W składających się na upamiętnianie praktykach i produktach pamięci grupa opowiada zwykle o sobie samej. Przywoływanie - głównie przez nieżydowskich mieszkańców - historii i kultury Żydów w przestrzeniach mniejszych miejscowości jest zatem sytuacją problematyczną etycznie. W artykule analizuję składające się na upamiętnienie praktyki (dni pamięci, wykłady, inscenizacje, spacery) i produkty pamięci (książki, filmy dokumentalne, wystawy w lokalnych muzeach, pomniki) dotyczące zagłady lokalnych Żydów pod względem formy, treści i zaangażowanych w nie aktorów społecznych. Pozwala to scharakteryzować, jak grupa postrzega samą siebie bądź chce być postrzegana w kontekście przywoływanej historii Zagłady. Ważne pozostaje, co w konkretnym wizerunku przeszłości pozostaje nieobecne i przemilczane. W artykule wyróżniam trzy strategie obrazowania zagłady Żydów: 1) neutralizowania i zamykania trudnych tematów; 2) równoważenia, wyłączania i podporządkowywania historii zagłady Żydów; 3) włączenia i uznania pamięci żydowskiej. Zastosowałam krytyczną analizę dyskursu, odwołując się m.in. do analizy przemocy filosemickiej Elżbiety Janickiej i Tomasza Żukowskiego. Przywołuję wyniki m.in. socjologicznych badań jakościowych zrealizowanych studiów przypadków w Bobowej, Dąbrowie Tarnowskiej i Rymanowie (2010-2016). Przeprowadziłam wówczas analizę danych zastanych, indywidualne wywiady pogłębione oraz wywiady grupowe, jak i obserwację uczestniczącą.
\end{abstract}




\title{
Słowa kluczowe
}

pamięć o Zagładzie, wspólnota pamięci, upamiętnianie, dziedzictwo żydowskie, Bobowa, Dąbrowa Tarnowska, Rymanów

\begin{abstract}
In the article I analyzed different strategies of representing the Holocaust in initiatives commemorating Jewish communities in local Poland. The annihilation of the Jews is the example of a difficult memory. The social phenomenon undermines the group values and social norms. With regard to local communities the difficult memory has often stemmed from the experience of "being close to the Shoah". The particular position toward suffering of Jewish community had become a ground for varied attitudes of (co)responsibility and (co)participation of members of local communities regarding the Holocaust. Generally, memory about those events was subject of a vernacular transmission after the war, yet it didn't become public one. In the consequence, in towns inhabited by numerous Jewish communities till the Holocaust, a specific community of memory had been shaped aftermath: characterized mainly by conspiracy of silence regarding Jewish history and culture. Yet, in the recent time in those social spaces one may observe more and more commemorative initiatives which has been invoking various aspects of the local Jewish heritage. Usually, in commemorative practices and products a group portraits itself. Thus, referring - by almost exclusively non-Jewish social actors - to Jewish history and culture has raised some ethical concerns. In the article I took into consideration form, content and social actors involved in selected commemorative practices (such as days of memory, lectures, walks, performances) and commemorative products (books, documentaries, inhibits of local museums, memorials) which concern the annihilation of the Jewish community. It enabled me to characterize a self-perception (actual or desired) of a group in the context of invoked history of the Holocaust. Important was what in this specific representation of the past remained absent or silenced. In the article I distinguished three strategies of representing the annihilation of the Jews, which are as follows: 1) neutralizing and closing up difficult themes; 2) counterbalancing, excluding and subordinating history of the Shoah; 3 ) including and recognizing the Jewish memory. I applied critical discourse analysis referring to Elżbieta Janicka and Tomasz Żukowski's study of philosemitic violence, among others. To this regard I related to sociological case studies carried on in Bobowa, Dąbrowa Tarnowska and Rymanow (2010-2016). I conducted desk research, both individual in-depth and focus group interviews, and participant observation.
\end{abstract}

\section{Key words}

memory of the Holocaust, community of memory, Jewish heritage, Bobowa, Dąbrowa Tarnowska, Rymanów

\section{Lokalne wspólnoty pamięci ${ }^{1}$}

Paul Connerton stwierdził, że „[...] jeśli w ogóle istnieje coś takiego jak pamięć społeczna, to najprędzej znajdziemy ją w [...] obrzędach upamięt-

\footnotetext{
${ }^{1}$ Artykuł powstał na podstawie materiałów zgromadzonych w dwóch projektach: 1. „Upamiętnianie przedwojennych społeczności żydowskich we współczesnej Polsce jako przejaw kulturowej traumy Zagłady", finansowanym ze środków NCN przyznanych na podstawie decyzji nr DEC-2013/09/N/HS6/00422; 2. „Społeczna antropologia pustki - Polska i Ukraina po II wojnie światowej", finansowanym przez Narodowy Program Rozwoju Humanistyki, nr umowy 0101/NPRH3/H12/82/2014.
} 
niania"2 ${ }^{2}$ Ten pragmatyczny aspekt pamięci wyraża się w praktykach i produktach pamięci - pamięć nie jest czymś, co mamy, ale czymś, co robimy³. Upamiętnianie pełni funkcję legitymizującą: „przez zwrócenie ludziom uwagi, że czymś uprawnionym jest pamiętać o danym wydarzeniu, że nie wiąże się z nim żaden stygmat, by mówić o nim publicznie [...]"4. Przynajmniej nie kiedy mówi się o nim w specyficzny sposób. W składających się na upamiętnianie praktykach i produktach pamięci grupa opowiada o samej sobie, potwierdzając, konfrontując się z własną tożsamością, negocjując jej znaczenia. Przywoływanie - głównie przez nieżydowskich mieszkańców - historii i kultury Żydów w przestrzeniach mniejszych miejscowości jest zatem sytuacją szczególną i problematyczną etycznie. Mianowicie zbiorowość mówi o sobie samej przez obrazowanie Innego.

Wzajemne zależności między pamięcią i tożsamością dobrze oddaje koncepcja „wspólnoty pamięci”, którą charakteryzuje to, że „nie zapomina o swojej przeszłości”, bo „angażuje się w opowiadanie wielokrotnie swej historii, tej konstytuującej narracji” ${ }^{5}$. Ludzie wzrastający w społeczność uczestniczą w „praktykach zaangażowania" - rytualnych, estetycznych, etycznych - definiujących reguły lojalności i obowiązków, które pozwalają zbiorowości trwać. Można powiedzieć, że następstwa Zagłady w mniejszych miejscowościach, w których mieszkały liczne społeczności żydowskie ${ }^{6}$, ukształtowały specyficzne powojenne wspólnoty pamięci ${ }^{7}$. Dla nich fundamentalnym doświadczeniem stało się „bycie blisko

${ }^{2}$ Paul Connerton, Jak społeczeństwa pamiętają, tłum. Marcin Napiórkowski, Warszawa: Wydawnictwa Uniwersytetu Warszawskiego, 2012, s. 144.

${ }^{3}$ Jeffrey Olick, From Collective Memory to the Sociology of Mnemonic Practices and Products [w:] Cultural Memory Studies. An International and Interdisciplinary Handbook, red. Astrid Erll, Ansgar Nünning, Berlin: Walter de Gruyter, 2008.

${ }^{4}$ Jens Rydgren, The Power of the Past. A Contribution to a Cognitive Sociology of Ethnic Conflict, „Sociological Theory” 2007, nr 25 (3), s. 230.

${ }^{5}$ Robert N. Bellah, Richard Madsen, William M. Sullivan, Ann Swidler i Steven M. Tipton, Habits of the Heart. Individualism and Commitment in American Life, Berkeley: University of California Press, 1985, s. 153.

${ }^{6}$ Te mniejsze miejscowości można nazwać sztetlami ze względu na specyficzną strukturę społeczną oraz sieć relacji ekonomicznych i społecznych z pobliskimi miasteczkami, większym prowincjonalnym miastem oraz okolicznymi wsiami, zob. The Shtetl. New Evaluations, red. Steven T. Katz, New York: New York University Press, 2007.

${ }^{7}$ Do odmiennego wniosku - o braku wspólnoty pamięci w powojennych mniejszych miejscowościach - doszli Jacek Nowak, Sławomir Kapralski i Dariusz Niedźwiedzki. Argumentują oni, że w społecznościach dawnych sztetli zabrakło przekazu międzypokoleniowego o żydowskiej społeczności. Autorzy zaobserwowali proces „banalnego zapominania” - wynikający m.in. z braku zainteresowania członków pokoleń urodzonych po wojnie oraz z braku emocji społecznych wobec dawnej społeczności żydowskiej. Wysiłki pojedynczych aktywistów działających na rzecz upamiętniania lokalnych Żydów nie traktują jako próby przechodzenia od pamięci komunikacyjnej do pamięci kulturowej. Problematyzują również istnienie pamięci komunikacyjnej o lokalnych Żydach. Zob. Jacek Nowak, Sławomir Kapralski i Dariusz Niedźwiedzki, On the Banality of Forgetting. Tracing the Memory of Jewish Culture 
Zagłady", będące punktem wyjścia zróżnicowanych postaw (współ)odpowiedzialności i (współ)uczestnictwa członków lokalnych społeczności w zagładzie Żydów. Trzeba tu wymienić udział części mieszkańców w mordowaniu, prześladowaniu, donoszeniu, organizowaniu czy uczestniczeniu w obławach, których celem byli ukrywający się Żydzi. Mimo powojennych procesów prowadzonych $\mathrm{z}$ tzw. dekretu sierpniowego ${ }^{8}, \mathrm{w}$ wielu wypadkach zbrodnie te nie zostały ujawnione i rozliczone. Istotne dla wspólnoty pozostawały też następstwa postawy bierności charakteryzującej się tym, że ktoś „wiedział o zbrodni, bądź widział, jak się dokonywała, nie przeciwdziałając jej bądź nie interweniując”․ Niepodjęcie działania, nawet jeśli wynikało z paraliżującego poczucia zagrożenia życia własnego i rodziny, niosło ze sobą następstwa moralne ${ }^{10}$. Postawy bierności były wewnętrznie zróżnicowane. Na uwagę zasługuje postawa „niechętnej bierności”11, często podszytej uczuciem satysfakcji, bo oto „najstraszniejsze, najbardziej skrycie oczekiwane [mściwe pragnienia - M.D.-D.] - choć przecież

in Poland, Berlin: Peter Lang, 2018. Myślę, że różnica może wynikać z odmiennej konceptualizacji pamięci o Żydach i o Zagładzie w lokalnych społecznościach. W potocznym wymiarze odbiega ona znacznie w swych treściach od etycznej pamięci o Zagładzie. Potoczny przekaz najstarszych mieszkańców województwa podkarpackiego zarejestrował m.in. Krzysztof Malicki. Wśród poruszanych przez jego rozmówców i rozmówczynie tematów znalazła się także problematyka postaw lokalnej społeczności nieżydowskiej - niechęci, przejawów wrogości, przejmowania majątku żydowskiego. Zob. Krzysztof Malicki, Poza wspólnota pamięci. Życie i Zagłada Żydów w pamięci mieszkańców regionu podkarpackiego, Warszawa: Wydawnictwo IFiS PAN, 2017, a także jego artykuł w tym tomie, pt. Pomiędzy niepamięciq a pamięciq ekskluzywnq. Współczesny Rzeszów wobec swojej żydowskiej przeszłości. W artykule koncentruję się na oficjalnych praktykach upamiętniających. Przekazowi potocznemu zarejestrowanemu podczas moich badań poświęciłam artykuł pt. «Wspomnienia (...) to jak w puszce zamknięto» wspólnoty pamięci $w$ byłych sztetlach po Zagładzie w niewielkich miejscowościach, który przygotowuję do publikacji w ramach projektu prof. Anny Landau-Czajki pt. „Związani historią. Stosunki polsko-żydowskie na ziemiach polskich".

${ }^{8}$ Dekret Polskiego Komitetu Wyzwolenia Narodowego z dnia 31 VIII 1944 r. o wymiarze kary dla faszystowsko-hitlerowskich zbrodniarzy winnych zabójstw i znęcania się nad ludnością cywilną i jeńcami oraz dla zdrajców Narodu Polskiego oraz jego późniejsze nowelizacje.

${ }^{9}$ Bernard Giesen, Triumph and Trauma, Boulder: Paradigm Publishers, 2004, s. 7.

${ }^{10}$ Zygmunt Bauman, Nowoczesność i Zagłada, tłum. Tomasz Kunz, Kraków: Wydawnictwo Literackie, 2009, wersja Kindle.

${ }^{11}$ Odwołuję się do typologii postaw socjolożki Antoniny Kłoskowskiej, która wyróżniła: „wrogą postawę aktywną”, „postawę niechętnej bierności”, „bierność współczującą”, „obojętność” oraz „niesienie pomocy” zob. Antonina Kłoskowska, Polacy wobec zagłady Żydów polskich. Próba typologii postaw, „Kultura i Społeczeństwo” 1988, nr 4, s. 111-127. Korzystam również z kategoryzacji postaw opartej na ustaleniach Kłoskowskiej oraz Szymona Datnera, czyli: a) sprawców i pomocników; b) tych, którzy stali obok (bystanders) - wrogich, nieprzyjaznych, obojętnych bądź współczujących; c) ratujących - mających zamiar pomóc bądź nie mających takiego zamiaru, chętnych bądź niechętnych ratujących, opłaconych bądź bona fide, okazjonalnych bądź długoterminowych, zob. Marek Kucia, Marta Duch-Dyngosz i Mateusz Magierowski, Anti-Semitism in Poland: Survey Results and a Qualitative Study of Catholic Communities, „Nationalities Papers” 2013, nr 42 (1), s. 8-26. 
dotychczas niemożliwe, nawet do jasnego pomyślenia - zaczęły się dziać"12. Do obszarów trudnej pamięci należy też zjawisko niesienia pomocy ukrywającym się Żydom, zróżnicowane m.in. ze względu na motywy ratujących, formy pomocy czy stosunek do ukrywających $\operatorname{się}^{13}$. W polskim społeczeństwie ratowanie Żydów nie cieszyło się szerokim przyzwoleniem społecznym, zarówno w czasie wojny, jak i w ocenie społecznej po wojnie, na co wskazywali też potomkowie tych, którzy udzielili pomocy szukającym ratunku Żydom. Powojenne wspólnoty pamięci charakteryzowały się zmową milczenia ${ }^{14}$ - sytuacją, gdy wszyscy wiedzą, co się stało, potrafią wskazać sprawców czy uczestników wydarzenia, natomiast wiedza na ten temat nie wychodzi poza wspólnotę. Jest przedmiotem przekazu potocznego, a zarazem przemilczenia na poziomie publicznym, co prowadzi do „rozdwojenia pamięci”, kiedy obserwujemy „napięcie między tym, czego doświadcza się osobiście, a tym, co jest publicznie przyjęte do wiadomości"15. Wiążą się z tym mechanizmy różnego typu zapominania zbiorowego ${ }^{16}$ i milczenia zbiorowego ${ }^{17}$. Tego typu „milczenie nie jest tylko produktem, ale też głównym źródłem strachu", z którym można zacząć sobie radzić, podejmując dyskusję nad kwestiami, pozostającymi do tej pory „nie do dyskusji”"18 - włączając je do publicznego dyskursu.

W tak scharakteryzowanych przestrzeniach społecznych coraz wyraźniejszy w ostatnich latach staje się społeczny fenomen przywoływania dziedzictwa

${ }^{12}$ Andrzej Leder, Prześniona rewolucja. Ćwiczenie z logiki historycznej, Warszawa: Wydawnictwo Krytyki Politycznej, 2014, s. 44. 0 tym typie postawy pisał już Jan Błoński w swoim sławnym eseju pt. Biedni Polacy patrzq na getto, który zauważył: „Wreszcie straciliśmy swój dom i w tym domu okupant zaczął Żydów zabijać. Czyśmy im solidarnie pomogli? Ilu z nas uznało, że to nie ich rzecz! Pomijam zwykłych zbójów, myślę o tych, wcale licznych, co się po cichu cieszyli, że Hitler załatwił nam «problem» żydowski...”

${ }^{13}$ Joanna B. Michlic, Piętno Zagłady. Wojenna i powojenna historia oraz pamięć żydowskich dzieci ocalałych $w$ Polsce, tłum. Adam Musiał, Warszawa: ŻIH, 2020. Autorka wyróżnia dwie skrajne postawy wobec ratowanych żydowskich dzieci: „oddanych wybawców” („główną motywacją ratowania dziecka była troska o jego życie i byt, bez względu na ewentualną zapłatę lub jej brak, za zapewnione schronienie i opiekę”, s. 106) oraz „ratujących oprawców”, stosujących wobec powierzonych im w opiekę dzieci przemoc i wyzysk.

${ }^{14}$ Conspiracy of silence, zob. Eviatar Zerubavel, The Elephant in the Room: Silence and Denial in Everyday Life, New York: Oxford University Press, 2006. W kontekście przemilczenia antyżydowskich postaw Polaków w powojennym dyskursie publicznym pojęcie zmowy milczenia zastosowała Joanna Tokarska-Bakir: How to Exit the Conspiracy of Silence? Social Sciences Facing the Polish-Jewish Relations, „East European Politics \& Societies” 2011, nr 25, s. 129-152. Antoni Sułek wskazał jako bardziej adekwatną kategorię „umowy społecznej”. Przychylam się jednak bardziej stosowania pojęcia „zmowy milczenia” jako typu dysfunkcyjnej umowy społecznej.

${ }^{15}$ Zerubavel, The Elephant in the Room..., s. IX.

${ }^{16}$ Paul Connerton, Seven Types of Forgetting, „Memory Studies” 2008, nr 1 (1), s. 59-71.

${ }^{17}$ Vered Vinitzky-Seroussi, Chana Tegger, Unpacking the Unspoken. Silence in Collective Memory and Forgetting, „Social Forces” 2010, nr 88 (3), s. 1103-1122.

${ }^{18}$ Undiscussables, zob. Zerubavel, The Elephant in the Room..., s. 6-8. 
żydowskiego i upamiętniania lokalnych społeczności. Elżbieta Janicka i Tomasz Żukowski zwracają uwagę, że ważniejsza niż powstanie licznych reprezentacji historii i kultury żydowskiej w Polsce pozostaje charakterystyka ich obrazowania, które zbyt często przybiera formę przemocy symbolicznej wobec żydowskiej mniejszości ${ }^{19}$. W artykule proponuję popatrzeć na fenomen upamiętniania jak na nielinearny, skomplikowany proces, gdy w przestrzeni publicznej przywoływane zostają obszary objęte do tej pory milczeniem i zapomnieniem. Niekoniecznie upamiętnianie musi prowadzić do nadużycia pamięci, w specyficznych warunkach społecznych ma potencjał przeobrażenia dotychczasowych „praktyk zaangażowania" wspólnot. Warto przeanalizować, czy i w jaki sposób są przedstawiane w inicjatywach: wielowiekowa obecność żydowskich społeczności; Zagłada i jej następstwa; oraz przeszłe i teraźniejsze postawy wobec Żydów. Liderzy pamięci, aktorzy społeczni inicjujący i trwale zaangażowani w inicjatywy upamiętniające, podejmując praktyki społeczne, zmieniają świadomość dyskursywną społeczności, pokazując inny od rozpowszechnionego modus operandi wobec dziedzictwa żydowskiego, oddziałując zatem na świadomość praktyczną, na rutynę codziennych działań. Podejmowane inicjatywy upamiętniające były zróżnicowane pod względem refleksyjności i sprawczości liderów pamięci ${ }^{20}$, jak i warunków strukturalnych, w których przyszło działać liderom. Można wyszczególnić trzy strategie dyskursywne pamięci o Żydach i Zagładzie w Polsce (niekiedy współwystępujące w obrębie jednej reprezentacji): krytyczną, afirmacyjną i etnonacjonalistyczną, które różni stosunek do pamięci żydowskiej. Strategia krytyczna uznaje perspektywę żydowską za równorzędną pamięci grupy własnej, dając jej przestrzeń do swobodnej ekspresji. Afirmacyjny dyskurs przefiltrowuje pamięć żydowską przez pamięć własnej zbiorowości, odrzucając te elementy, które podważają pozytywny wizerunek grupy. Etnonacjonalistyczna strategia wyraźnie przerysowuje obcość pamięci żydowskiej, którą postrzega jako wrogą i podporządkowaną pamięci grupy własnej. Dyskursy afirmacyjny i etnonacjonalistyczny łączy postrzeganie Żydów jako grupy radykalnie innej, budzącej ambiwalentne uczucia: od niechęci po fascynację. Wspólnym rdzeniem antysemityzmu i filosemityzmu jest wyłączenie poza nawias własnej wspólnoty tego, co różne ${ }^{21}$. Dyskurs krytyczny, deklarując „pamięć wspomnienie” i po-

${ }^{19}$ Elżbieta Janicka, Tomasz Żukowski, Przemoc filosemicka? Nowe polskie narracje o Żydach po roku 2000, Warszawa: Instytut Badań Literackich PAN, 2016.

${ }^{20}$ Zob. Anthony Giddens, Stanowienie społeczeństwa. Zarys teorii strukturacji, tłum. Stefan Amsterdamski, Poznań: Zysk i S-ka, 2013; Margaret S. Archer, Morphogenesis versus Structuration. On Combining Structure and Action, „The British Journal of Sociology” 1982, nr 33 (4), s. 455-483.

${ }^{21}$ Zygmunt Bauman, Allosemitism. Premodern, Modern, Postmodern [w:] Modernity, Culture, and 'the Jew', red. Bryan Cheyette, Laura Marcus, Stanford: Stanford University Press, 1998. 
trzebę „przepracowania pamięci”22, jako jedyny nawołuje do przeformułowania tożsamości zbiorowej i zauważa, że w przeciwnym razie dochodzi do „pamięci powtórzenia", reprodukowania niechęci i wrogości. W artykule przeanalizuję wyróżnione dyskursy na przykładzie trzech przypadków upamiętniania Zagłady w mniejszych miejscowościach.

Dwa procesy, „przepracowywania” i „nadużywania pamięci”, traktuję jako przeciwstawne punkty kontinuum mierzenia się z trudną pamięcią, o różnej gradacji przejawiania się. Na poziomie zbiorowości o przepracowywaniu można mówić wtedy, gdy członkowie grupy nabywają krytyczny dystans do przeszłości grupy własnej. Jest to możliwe m.in. dzięki otwarciu sfery publicznej na inne perspektywy pamięci i przywołaniu nawet tych wydarzeń, które podważają deklarowane wartości i normy grupowe, czego rezultatem zwykle jest problematyzacja dominujących wizji tożsamości i pamięci grupowej. Uwzględniłam przy tym postulat Theodora Adorno ${ }^{23}$, który przestrzegał przed rozumieniem procesu przepracowywania jako pozwalającego raz na zawsze zamknąć pewien rozdział historii przez wskazanie konkretnego punktu dojścia. Z tego powodu używam formy niedokonanej, kładąc nacisk na trwanie postawy świadomego pamiętania. $\mathrm{W}$ analizowanych inicjatywach upamiętnienia zastanawiam się zatem, czy oferują one możliwość zmierzenia się z tym, co trudne w kontekście obrazowania lokalnej historii Zagłady.

\section{Trzy studia przypadków}

Mój wybór padł na trzy miejscowości: Bobową, Dąbrowę Tarnowską oraz Rymanó $w^{24}$ - z kilku powodów. Wszystkie one znajdowały się w granicach historycznego terytorium Galicji, do dziś postrzeganego jako przestrzeń mityczna w kształtowaniu się tożsamości współczesnych lokalnych społeczności, jak i przedstawicieli dawnych społeczności żydowskich. Miejscowości te znalazły się w czasie okupacji w dystrykcie krakowskim Generalnego Gubernatorstwa, choć w granicach innych powiatów: Bobowa - jasielskiego, Dąbrowa Tarnowska - tarnowskiego, Rymanów - krośnieńskiego. Nie objęła ich okupacja ZSRR w latach 1939-1941, nie znalazły się po wojnie w granicach Ukraińskiej SRR i nie były dotknięte przesiedleniami społeczności polskiej w czasie wojny bądź tuż po jej zakończeniu. Obecnie Bobowa i Dąbrowa Tarnowska należą do województwa małopolskiego, Rymanów - podkarpackiego. Ich centra w dużym stopniu

${ }^{22}$ Paul Ricoeur, Pamięć, historia, zapomnienie, tłum. Janusz Margański, Kraków: Universitas, 2012.

${ }^{23}$ Theodor Adorno, What Does Coming to Terms with the Past Mean?, tłum. Timothy Bahti i Geoffrey Hartman [w:] Bitburg in Moral and Political Perspective, red. Geoffrey H. Hartman, Bloomington: Indiana University Press, 1986, s. 114-129.

${ }^{24}$ W 2020 r., według Banku Danych Lokalnych, Bobowa liczyła 3140 mieszkańców (gmina 9804); Dąbrowa Tarnowska - 11865 (21 254); Rymanów - 3807 (15 910). 
zachowały dawny układ urbanistyczny, historyczną siatkę ulic, przetrwało tam wiele domów i kamienic sprzed wojny. Związane ze sławnymi galicyjskimi dworami chasydzkimi i miejscami pochówku wielkich cadyków, przyciągają liczne pielgrzymki chasydzkie. W ostatnich dwóch dekadach w miejscowościach tych zostały odrestaurowane bądź odremontowane synagogi, przy czym różne były stan techniczny budynków, status własności oraz funkcje, które pełniły wcześniej i po remoncie. Od kilku lat podejmowano tam inicjatywy upamiętniające społeczności żydowskie, zróżnicowane w formie i biorących w nich udział aktorach społecznych. Historie tych miejscowości nie weszły do szerszej świadomości społecznej Polaków. Nie znalazły się w kanonie pamięci kulturowej polskiego społeczeństwa. Pewną rozpoznawalność w kontekście pamięci o Zagładzie i Żydach, głównie wśród badaczy bądź osób zainteresowanych tematyką, zyskała Dąbrowa Tarnowska ze względu na monografię Jana Grabowskiego ${ }^{25}$ dokumentującą udział ludności nieżydowskiej powiatu dąbrowskiego w obławach na ukrywających się Żydów. W artykule skupię się na wybranych inicjatywach upamiętniających z perspektywy obrazowania Zagłady, w tym przedstawiania postaw społeczności lokalnych. Poniżej przedstawiam w formie tabeli krótkie podsumowanie każdego ze studiów przypadku ${ }^{26}$.

Tabela 1. Podsumowanie trzech studiów przypadku

\begin{tabular}{|l|l|l|l|}
\hline & Bobowa & Dąbrowa Tarnowska & Rymanów \\
\hline $\begin{array}{l}\text { Dominujący } \\
\text { dyskurs pamięci }\end{array}$ & afirmacyjny & etnonacjonalistyczny & krytyczny \\
\hline Typ inicjatyw & lokalnie odgórne & lokalnie odgórne & oddolne \\
\hline
\end{tabular}

${ }^{25}$ Jan Grabowski, Judenjagd. Polowanie na Żydów 1942-1945. Studium dziejów pewnego powiatu, Warszawa: Stowarzyszenie Centrum Badań nad Zagładą Żydów, 2011.

${ }^{26}$ Studia przypadku zrealizowałam w latach 2010-2016. W odniesieniu do metod pozyskiwania materiału empirycznego zaplanowane zostały one tak, by dane reprezentowały różne aspekty pamięci. Przeprowadziłam analizę danych zastanych oraz badania jakościowe (63 nieustrukturyzowane wywiady indywidualne z przedstawicielami: a) liderów pamięci, inicjującymi upamiętnianie i długotrwale w nie zaangażowanymi, b) zwykłych mieszkańców, zarówno z tymi urodzonymi przed wojną, jak i z tymi należącymi do następnych pokoleń, zaangażowanych bądź nie w upamiętnianie, c) żydowskich społeczności oraz d) ekspertów zajmujących się profesjonalnie dziedzictwem żydowskim). Dodatkowo zrealizowałam 5 zogniskowanych wywiadów grupowych, m.in. z liderami lokalnymi, zwykłymi mieszkańcami oraz z młodzieżą szkolną, przy czym komplet fokusów udało mi się zrealizować w Bobowej, oraz obserwację uczestniczącą w każdej miejscowości. Ponadto w 2019 r. realizowałam w Rymanowie i okolicznych miejscowościach wywiady narracyjne głównie z przedstawicielami najstarszego pokolenia w ramach projektu pt. „Społeczna antropologia pustki - Polska i Ukraina po II wojnie światowej". 


\begin{tabular}{|c|c|c|c|}
\hline $\begin{array}{l}\text { Status synagogi } \\
\text { i cmentarza } \\
\text { żydowskiego }\end{array}$ & $\begin{array}{l}\text { własność Gminy } \\
\text { Wyznaniowej } \\
\text { Żydowskiej (GWŻ) } \\
\text { w Krakowie; } \\
\text { funkcje religijne dla } \\
\text { pielgrzymujących } \\
\text { chasydów do grobu } \\
\text { Salomona Halberstama; } \\
\text { obiekty udostępniane } \\
\text { zwiedzającym }\end{array}$ & $\begin{array}{l}\text { synagoga jest własnością } \\
\text { gminy Dąbrowa } \\
\text { Tarnowska; cmentarz } \\
\text { GWŻ w Krakowie; } \\
\text { synagoga pełni funkcję } \\
\text { instytucji kultury - } \\
\text { Ośrodka Spotkania } \\
\text { Kultur (OSK), wystawa } \\
\text { stała po części dotyczy } \\
\text { dąbrowskich Żydów; na } \\
\text { cmentarzu znajduje się } \\
\text { grób cadyka Mordechaja } \\
\text { Dawida Ungera; obiekty } \\
\text { udostępniane zwiedzającym }\end{array}$ & $\begin{array}{l}\text { synagoga jest własnością } \\
\text { Avrahama Reicha, } \\
\text { z chasydzkiej kongregacji } \\
\text { uczniów Menachema } \\
\text { Mendla w Nowym Jorku, } \\
\text { cmentarz - własnością } \\
\text { FODŻ; oba obiekty } \\
\text { pełnią funkcje religijne } \\
\text { dla pielgrzymujących } \\
\text { chasydów do grobu m.in. } \\
\text { Menachema Mendla, } \\
\text { obiekty są udostępniane } \\
\text { zwiedzającym }\end{array}$ \\
\hline $\begin{array}{l}\text { Zaangażowanie } \\
\text { żydowskich } \\
\text { aktorów } \\
\text { społecznych }\end{array}$ & \begin{tabular}{|l|} 
głównie formalne \\
kontakty reprezentantów \\
społeczności żydowskich \\
z przedstawicielami \\
władz, szczególne \\
zaangażowanie \\
w związku z ochroną \\
materialnego dziedzictwa \\
żydowskiego, generalnie \\
niezaangażowani \\
w praktyki upamiętnia- \\
jące; szansą na \\
zmianę jest otwarcie \\
w 2020 r. izby pamięci \\
przez lokalnego \\
przedsiębiorce, który \\
na prośbę potomka \\
właściciela domu nazwał \\
Izbę „Domem Landaua”
\end{tabular} & $\begin{array}{l}\text { uczestniczenie reprezen- } \\
\text { tantów społeczności } \\
\text { żydowskich w ceremonii } \\
\text { otwarcia OSK, brak } \\
\text { wpływu na lokalne } \\
\text { upamiętnianie }\end{array}$ & $\begin{array}{l}\text { od etapu planowania, } \\
\text { przez uczestnictwo po } \\
\text { przywołanie źródeł } \\
\text { żydowskich, miejsce dla } \\
\text { perspektywy żydowskiej, } \\
\text { wyróżniająca się rola } \\
\text { członkini drugiego } \\
\text { pokolenia po Zagładzie, } \\
\text { której rodzina odkupiła } \\
\text { kamienicę od jednego } \\
\text { z mieszkańców, będącą } \\
\text { własnością jej dziadków } \\
\text { i na parterze której mają } \\
\text { miejsce różne wydarze- } \\
\text { nia związane z historią } \\
\text { i kulturą rymanowskich } \\
\text { Żydów; określana przez } \\
\text { obecną właścicielkę } \\
\text { „domem żydowskim” }\end{array}$ \\
\hline Liderzy pamięci & $\begin{array}{l}\text { burmistrz (pozostający } \\
\text { na stanowisku), a od roku } \\
2020 \text { również lokalny } \\
\text { przedsiębiorca, właściciel } \\
\text { „Domu Landaua”, który } \\
\text { zainicjował upamiętnienie } \\
\text { oddolne }\end{array}$ & $\begin{array}{l}\text { burmistrz (zmienił się } \\
\text { w } 2014 \text { r.); dyrektor } \\
\text { OSK oraz alternatywni } \\
\text { wobec dominującego } \\
\text { upamiętnienia } \\
\text { liderzy pamięci, } \\
\text { m.in. nauczycielka } \\
\text { miejscowego liceum }\end{array}$ & $\begin{array}{l}\text { wielu różnych liderów } \\
\text { pamięci: społeczników, } \\
\text { potomków lokalnych } \\
\text { Żydów, nauczycieli, } \\
\text { dziennikarzy, w dużej } \\
\text { części mieszkających } \\
\text { na co dzień poza } \\
\text { Rymanowem }\end{array}$ \\
\hline $\begin{array}{l}\text { Dominujące } \\
\text { strategie } \\
\text { dyskursywne }\end{array}$ & $\begin{array}{l}\text { neutralizowania } \\
\text { i zamykania trudnych } \\
\text { tematów }\end{array}$ & $\begin{array}{l}\text { równoważenia, } \\
\text { wyłączenia } \\
\text { i podporządkowania }\end{array}$ & $\begin{array}{l}\text { uznania pamięci } \\
\text { żydowskiej }\end{array}$ \\
\hline $\begin{array}{l}\text { Charakter } \\
\text { relacji między } \\
\text { uczestnikami }\end{array}$ & formalne & formalne & nieformalne \\
\hline $\begin{array}{l}\text { Reprezentatyw- } \\
\text { na praktyka }\end{array}$ & $\begin{array}{l}\text { Inscenizacja } \\
\text { chasydzkiego wesela } \\
\text { Jak cadyk z Bobowej } \\
\text { córkę wydawał }\end{array}$ & $\begin{array}{l}\text { Spektakl teatralny } \\
\text { Dzień gniewu wystawiony } \\
\text { przez Teatr Nie Teraz }\end{array}$ & $\begin{array}{l}\text { Marsz Pamięci podczas } \\
\text { Dni Pamięci o Żydowskiej } \\
\text { Społeczności Rymanowa }\end{array}$ \\
\hline $\begin{array}{l}\text { Lokalizacja } \\
\text { pamięci }\end{array}$ & Dom Landaua & Ośrodek Spotkania Kultur & Dom żydowski \\
\hline
\end{tabular}


Inicjatywy upamiętniające wprowadzają do publicznej przestrzeni poszczególnych miejscowości obszary poddawane przez dziesięciolecia zapomnieniu i milczeniu. To, w jakiej mierze działania upamiętniające zyskają szerokie przyzwolenie społeczne, zależy od podejmowanej przez nie tematyki, składających się na nie praktyk i produktów pamięci, ich treści oraz formy, oraz od liderów pamięci, od tego, kim są w relacji do miejscowej wspólnoty pamięci. Konkretne, lokalne konfiguracje tych i też wielu innych elementów warunkują to, czy charakter inicjatyw odzwierciedla przede wszystkim świadomość liderów pamięci i znajduje akceptację wśród nielicznej publiczności, czy wpisuje się w postawy większości społeczności wobec dziedzictwa żydowskiego. Lokalne upamiętnianie uwarunkowane jest także strukturalnymi ograniczeniami i możliwościami obserwowanymi w danym momencie na poziomie narodowym czy globalnym. Dojście w Polsce do władzy Prawa i Sprawiedliwości w 2015 r. i propagowana przez ten obóz polityka historyczna, w dużym stopniu etnonacjonalistyczna, po części afirmacyjna, stały się znaczącym czynnikiem, który może oddziaływać na podejmowane działania przez liderów pamięci. W dalszej części artykułu skupię uwagę na inicjatywach, które odzwierciedlają dominujący dyskurs upamiętniania w każdej z omawianych miejscowości z perspektywy obrazowania Zagłady, w tym przywoływania postaw członków lokalnej społeczności.

\section{Neutralizowanie i zamykanie trudnych tematów}

W upamiętnieniu w Bobowej przejawiało się wyraźnie zjawisko, które Michael Meng określił jako „zbawczy kosmopolityzm”27 - kiedy zainteresowanie miejscami żydowskimi służy jako dowód tolerancyjnej i otwartej postawy (zarówno przeszłej, jak i współczesnej) lokalnych społeczności wobec tego, co inne. Sentymentalny obraz wielokulturowości pozwala uniknąć konfrontowania się z tym, co trudne i bolesne w historii Zagłady. W czerwcu 2013 r. w Bobowej odbyła się pierwsza edycja Dni Bobowej z Kulturą Żydowską, reprezentatywna dla tego upamiętniania. Drugiego dnia, w niedzielne popołudnie mieszkańcy Bobowej i okolic tłumnie stawili się na inscenizacji chasydzkiego wesela zatytułowanej Jak cadyk z Bobowej córkę wydawał. Za pierwowzór posłużyły uroczystości weselne córki bobowskiego cadyka Nechamy Gold z 1931 r., z których zachował się fotoreportaż Ze'eva Aleksandrowicza dla „Ilustrowanego Kuriera Codziennego". W inscenizacji wzięli udział aktorzy Teatru im. Ludwika Solskiego w Tarnowie, pomysłodawcy przedsięwzięcia. W młodych chasydów wcielili się uczniowie bobowskich szkół. Uroczystość zaślubin prowadził prof. Jonathan Webber, urodzony w Anglii, a mieszkający w Polsce badacz kultury galicyjskich Żydów i religijny Żyd. W rekonstrukcji wesela uczestniczyła córka Nechamy Gold, Shoshana Stern, w towarzystwie męża Williama Sterna. Tego dnia przypadła rocz-

${ }^{27}$ Redemptive cosmopolitism, zob. Michael Meng, Shattered Spaces. Encountering Jewish Ruins in Postwar Germany and Poland, Cambridge, MA: Harvard University Press, 2011. 
nica śmierci cadyka Salomona Halberstama i w tłumie przechadzało się kilku chasydów. Jedynym akcentem związanym z zagładą lokalnych Żydów był krótki moment, kiedy Stern, przemawiając ze sceny ustawionej na rynku, przyznał, że z żoną mają mieszane uczucia, stojąc przed mieszkańcami w miejscu, skąd żona musiała uciekać jako dziecko wraz z matką i rok starszym bratem. Przypomniał, że w czasie wojny ojciec Shoshany zginął we Lwowie wraz z jej dziadkiem - sławnym cadykiem Bencjonem Halberstamem, oraz wieloma członkami rodziny. Mężczyzna zakończył przemówienie, przekazując tablicę pamiątkową w podziękowaniu burmistrzowi i urzędowi miasta za zaangażowanie w ochronę miejsc żydowskich w Bobowej. Burmistrz, odbierając tablicę pamiątkową, odniósł się do motywów prowadzonych inicjatyw upamiętniających:

Dedykuję to bobowianom, wszystkim tym, którzy przyczyniają się w jakikolwiek sposób do tego, że relacje między społecznościami są dobre, że przyjeżdżający chasydzi do Bobowej mogą czuć się jak u siebie. [...]. To świadczy o tym, że jesteśmy ludźmi tolerancyjnymi, natomiast obowiązkiem naszego samorządu jest dbać o to, by ta kultura żydowska, te pozostałości, obiekty, też w jakiś sposób mogły funkcjonować i mogły być wizerunkiem naszej gminy ${ }^{28}$.

Inny charakter miała zorganizowana poprzedniego dnia sesja historyczna, w której wzięli udział burmistrz, przedstawiciele urzędu miasta oraz niektórzy mieszkańcy. W jej trakcie zainteresowana lokalnym dziedzictwem żydowskim regionalistka Barbara Kowalska wygłosiła wykład pt. $Z$ historii bobowskich Żydów ${ }^{29}$. Na przykładzie tego wystąpienia oraz praktyki upamiętniającej dom rodziny Schneiderów widoczna była niejednoznaczność procesu odkrywania obszarów do tej pory przemilczanych w lokalnej pamięci publicznej. Z jednej strony prelegentka zobrazowała dziedzictwo żydowskie jako składową lokalnej tożsamości. Przywołała trudne obrazy przemocy wobec Żydów zgromadzonych $\mathrm{w}$ bobowskim getcie zamieszczone w pisanej retrospektywnie od $1955 \mathrm{r}$. kronice, autorstwa jej ojca:

Najtragiczniejszy dzień w historii bobowskich Żydów to dzień likwidacji getta - 14 VIII 1942 r. - piątek. Wczesnym świtem pojawiły się w miasteczku oddziały policji niemieckiej i ukraińskiej. Wpadały one do domów żydowskich i w nieludzki sposób wyciągały swe ofiary, bijąc je bykowcami. Przy okazji przeszukiwano ich mieszkania. Niemowlęta wyrzucano przez okna na rynek. Wszystkich osadzono na rynku - musieli trzymać ręce wzniesione do góry. Niektórzy próbowali ucieczki, ale przepłacili to życiem. Zdarzały się przypadki poświęcania się dzieci za rodziców. Wszystkich spotkał ten sam los śmierć. Na rynku słychać było niesamowity krzyk, płacz dzieci i jęki starców.

${ }^{28}$ Jak cadyk z Bobowej córkę wydawał, transmisja z uroczystości, https://www.youtube. com/watch?v=Rqe3dPUrV2A (dostęp 6 VI 2021 r.).

${ }^{29}$ Barbara Kowalska, Z historii bobowskich Żydów, „Nasza Bobowska Gmina” 2013, s. 9-11. 
Przez cały dzień trzymano ich na rynku, a wieczorem i całą noc wywożono ich samochodami ${ }^{30}$.

$\mathrm{Z}$ drugiej strony regionalistka przywołała sposób, w jaki - można przypuszczać - nieżydowska społeczność próbowała wyjaśnić, co się wydarzyło: „Żydzi przeczuwali, a raczej byli pewni, że spotka ich coś tragicznego, a to za sprawą przepowiedni, którą ogłosił rabin bobowski Ben Cion Halberstam. Przepowiedział on, że w roku, w którym wyginą kuropatwy, oni też zginą". Motyw przepowiedni był jednym z toposów pamięci potocznej, łączących przekleństwo, które mieli sprowadzić na siebie Żydzi, z zarzutem bogobójstwa ${ }^{31}$. Można to uznać za przejaw antyjudaizmu. Całą przypowieść o zniknięciu kuropatw przedstawiła jedna z interlokutorek badań realizowanych w Bobowej na początku lat dziewięćdziesiątych:

Proszę panią, wie pani co, opowiadania Żydów bobowskich, takich starych Żydówek, tu była taka Najmanowa, Bajwingierówna, potem była Cyngier - tu na dole mieszkała, potem Plachtery tam były w górze - to oni - myśmy dobrze żyli z nimi, no bo w sumie - każdy człowiek ma prawo do życia, skoro się urodził, to musi żyć. Powinien, nie? Proszę panią, to one mówiły tak, tak zawsze mówiła ta Cyngierka do mojej mamy, do ojca:

- „ha [...], panie Sz.” - bo oni taki mieli akcent - „niedobrze się dzieje”.

- „no, co jest Cyngierowa?"

- „Panie, a są kuropatwy” - to było w czasie proszę panią okupacji - „no panie, a są kuropatwy?". A on zdumiony mówi: y to jest fakt - no to już nie miał... najwyraźniej. Przecież do tych kapłanów, do tego Kajfasza i do tych wielu innych, prawda, szli z tym Panem Jezusem ci żołnierze tego, bili i targali i to, to oni sobie ręce umywali, tak? A przecież ci kapłani, to byli Żydzi. Żydzi. Ale oni niezależnie - to ja mówię od siebie - są winni, bo jeśli byli kapłanami, tymi dostojnikami,

- „Dlaczego wy się tak pytacie?”

- „No panie, niech go pan zapyta się chłopów, czy są tu kuropatwy?” - bo tu były i są takie łąki te wikliny. Dzikie kuropatwy. I faktycznie tych kuropatw nie było. No nie było. Naprawdę. Więc tata po jakimś czasie mówi:

- „no Cyngierowa, no nie ma tych kuropatw”. Na to ona:

- „Kuropatwy wyginęły, to my też zginiemy”. I ona wtedy powiedziała tak do ojca: „No, panie, Pan Jezus nas przeklął”.

A ona była stara Żydówka, ona no wtedy, kiedy ja mogłam mieć 18-20 lat [...]. A tata mówi: „No to powiedże mi Cyngierka, co to znaczy?”

„No Sz., jak cię szanuje, to my go już teraz się wykończymy. Nas wykończą. Bo nie ma kuropatw, a w naszych opisach, w naszych książkach pisze, że się będziemy tułać po całym świecie".

\section{${ }^{30}$ Ibidem, s. 10 .}

${ }^{31}$ Zob. Alina Cała, Wizerunek Żyda w polskiej kulturze ludowej, Warszawa: Oficyna Naukowa, 2005; Joanna Tokarska-Bakir, Legendy o krwi. Antropologia przesqdu, Warszawa: W.A.B., 2008. 
Tak że oni wiedzieli, że... jak przyszli tutaj, co to okupacja była, to oni panicznie się bali ${ }^{32}$.

Trudno powiedzieć, kiedy przepowiednia się rozpowszechniła. Po wojnie mogła pełnić wiele funkcji: potocznego wyjaśnienia skali zbrodni i jej następstw czy zwolnienia z odpowiedzialności za postawy grupy własnej. Z taką quasi-apokaliptyczną wizją wymordowania żydowskich mieszkańców, zapowiedzianą, a jednocześnie przerywającą nagle codzienną egzystencję, współgrał przedwojenny sielankowy obraz relacji międzygrupowych zaprezentowany w prelekcji regionalistki:

Nic nie zburzyło dobrych sąsiedzkich stosunków, i tak w spokoju i ciszy, „jak u Pana Boga za piecem" mieszkali Żydzi w Bobowej przez 207 lat. Ale gdy w mieście pojawili się „panowie życia i śmierci”, runął stary świat. Już nic nie było takie jak dawniej. Obraz Bobowej z tamtych lat pozostał tylko na kartach kroniki naszego miasta ${ }^{33}$.

Innym przykładem przywoływania, a jednocześnie zakrywania obszarów trudnej pamięci był przekaz o losach własności lokalnych Żydów. Kowalska wskazała, jak Niemcy wywieźli meble, bieliznę, rzeczy z domów żydowskich oraz jak „na rozkaz Niemców rozebrano i wywieziono 82 domy żydowskie”, i podsumowała: „Pozostałe domy żydowskie wykupili od gminy mieszkańcy Bobowej w latach 1968/1969"34. Natomiast cytowana przez nią kronika we wpisie o likwidacji getta wspomniała o udziale lokalnej społeczności w rabunku:

Majątkiem, jaki jeszcze pozostał, „zaopiekowali się” z miasta i niektórzy ze wsi obywatele przez co poprawili sobie byt na parę ładnych lat - taka okazja, jaka się wówczas nadarzyła nigdy się nie powtórzy, a zdobyty majątek nazwano „piątkowym”35.

Milczenie przybrało tu ukrytą formę ${ }^{36}$. Praktyki upamiętniające przysłoniły potoczną pamięć o rabowaniu majątku żydowskiego oraz o nieuregulowanej sytuacji prawnej części nieruchomości w Bobowej. Potwierdziła to uroczystość, zorganizowana tuż po sesji historycznej, czyli: „Odsłonięcie tablicy pamiątkowej przed ostatnim oryginalnym domem żydowskim w Bobowej - Domem Schneiderów przy ul. Grunwaldzkiej 1 (obok Urzędu Miejskiego)", jak napisano w programie wydarzenia. W artykule zamieszczonym na portalu „Bobowa24” pt. Dni

${ }^{32}$ Mam na myśli projekt badawczy realizowany pod kierownictwem Jonathana Webbera i Andrzeja Palucha „Pamięć kultury żydowskiej wśród mieszkańców Podkarpacia”. Miałam do dyspozycji jedynie transkrypcję wywiadu, pozostawiłam więc zapis oryginalny, ponieważ nie miałam możliwości jego zweryfikowania; Wywiad nr 21, Bobowa.

${ }^{33}$ Kowalska, Z historii bobowskich Żydów..., s. 11.

${ }^{34}$ Ibidem, s. 10.

35 „Kronika” Mieczysława Kowalskiego, maszynopis, udostępnione fragmenty.

${ }^{36}$ Covert silence, Vinitzky-Seroussi, Tegger, Unpacking the Unspoken... 


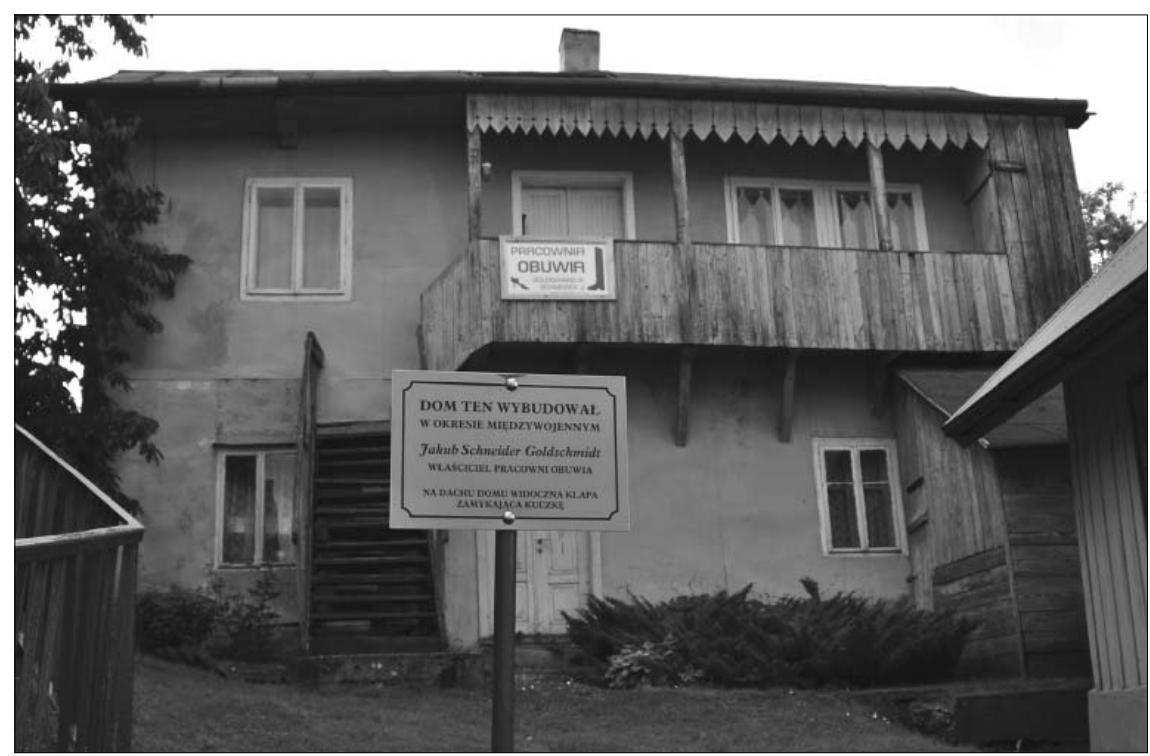

Dom Schneiderów przy ul. Grunwaldzkiej 1. Zdjęcie zostało wykonane w 2013 r. podczas uroczystości odsłonięcia tablicy pamiątkowej o treści: „Dom ten wybudował w okresie międzywojennym Jakub Schneider Goldschmidt, właściciel pracowni obuwia. Na dachu domu widoczna klapa zamykająca kuczkę" (fot. Marta Duch-Dyngosz)

Bobowej na półmetku pojawiła się informacja o upamiętnieniu „ostatniego zachowanego domu żydowskiego".

Kierunek upamiętniania potwierdziły kolejne Dni Bobowej z Kulturą Żydowską „Szalom”. W edycjach z 2015 i 2016 r. głównym tematem była pomoc, której mieszkańcy Bobowej mieli udzielić Żydom w czasie wojny. Dobrze została ona wkomponowana w mit wielokulturowego miasteczka. Burmistrz w relacji filmowej z edycji w 2015 r. przyznał:

[...] znawczyni historii Żydów, szczególnie z Bobowej, zaprezentowała nam cenne zapiski starych bobowian [...] dotyczące właśnie relacji mieszkańców Bobowej i między Żydami. Wynikało z nich, że też nasi mieszkańcy narażali swoje życie, ratując życie właśnie Żydów choćby podczas drugiej wojny światowej, i to jest piękne. To właśnie pokazuje obraz relacji między mieszkańcami Bobowej a społecznością żydowską. Przez ponad dwieście lat nie było tutaj znaczących konfliktów, nieporozumień. Wzajemny szacunek, zrozumienie i tolerancja ${ }^{37}$.

${ }^{37}$ Dni Bobowej z kulturq żydowskq - Szalom 2015, https://www.youtube.com/watch?v=ovAuPgSjlwM (dostęp 22 XI 2021 r.). 
W następnych latach wydarzenia nie podejmowały tematyki Zagłady lokalnych Żydów. Zapraszane były zespoły klezmerskie - krakowski zespół Sholem oraz pochodzący z Kielecczyzny zespół Chmielnikers. W 2018 r. teatr Drugi Brzeg z Krakowa przedstawił spektakl pt. Piosenka o złotej krainie, który opowiada o „młodym Żydzie - wiecznym tułaczu”. Poza 2017 r. bobowskie upamiętnianie nie objęło ani rocznicy likwidacji getta w Bobowej, ani miejsc, gdzie znajdują się masowe groby bobowskich Żydów ${ }^{38}$. Na przykład zbiorową mogiłę ulokowaną we wsi Stróżówka koło Gorlic trudno było znaleźć, wyglądała na opuszczoną39. Brakowało tam charakterystycznego oznaczenia miejsca pamięci narodowej bądź innych prowadzących do niej oznaczeń. Co więcej, miasto nie włączyło się w obchody likwidacji gett w regionie: Starym Sączu, Limanowej, Gorlicach, Białej Niżnej koło Grybowa, Nowym Sączu. Odbywały się one od 2015 r. z inicjatywy organizacji pozarządowej Sądecki Sztetl z Nowego Sącza. W Bobowej zabrakło przywołania pamięci żydowskiej: relacji, świadectw, wspomnień bobowskich ocalałych. Można zatem powiedzieć, że reprezentacja zagłady bobowskich Żydów kształtowała się według reguł dyskursu afirmacyjnego - dostrzegano partykularyzm Holokaustu i jego następstwa dla lokalnej wspólnoty, jednocześnie pamięć o tragicznych wydarzeniach przefiltrowana została przez pozytywny wizerunek własnej grupy.

\section{Równoważenie, wyłączenie i podporządkowanie dziedzictwa żydowskiego}

Decyzja władz Gminy Dąbrowa Tarnowska o odrestaurowaniu monumentalnej synagogi rozpoczęła etap lokalnie odgórnego upamiętniania w tej miejscowości. W bożnicy do lat siedemdziesiątych modliła się niewielka grupa dą-

\footnotetext{
${ }^{38}$ W 2017 r. na cmentarzu żydowskim upamiętniono 75. rocznicę likwidacji getta. Byli obecni przedstawiciele chasydzkiej społeczności nowosądeckiej, burmistrz Bobowej i przedstawiciele samorządu, Adam Bartosz z Muzeum Okręgowego w Tarnowie, Fundacja AntySchematy2 z Tarnowa, przedstawiciele Sztetlu Dukla, Sztetlu Nowy Sącz, proboszcz parafii. Informacja za: http://antyschematy2.com/upamietnienie-75-rocznicy-likwidacji-getta-wbobowej/ (dostęp 10 II 2021 r.).

${ }^{39}$ Duża część Żydów z bobowskiego getta zginęła, rozstrzelana w masowych egzekucjach - najprawdopodobniej 700 osób w lesie Garbacz we wsi Stróżówka koło Gorlic, część w Białej Niżnej koło Grybowa, niektórzy w lesie Dąbry w okolicach Rzepiennika Strzyżewskiego. Część trafiła do Gorlic, skąd została przetransportowana do Bełżca, zob. Elżbieta Rączy, Sytuacja Żydów w powiecie gorlickim w okresie okupacji niemieckiej [w:] Dzieje społeczności żydowskiej powiatu gorlickiego podczas okupacji niemieckiej 1939-1945, red. Michał Kalisz, Elżbieta Rączy, Rzeszów: Instytut Pamięci Narodowej, 2015, s. 47. Na pomniku w lesie we wsi Stróżówka znajduje się napis: „W tym grobie masowym spoczywają szczątki około 700 Żydów z Gorlic i Bobowej, ofiar rzezi hitlerowskiej, zamordowanych bestialsko w dniu 14 sierpnia 1942 roku. Wystawienie tego grobu i opieka nad tym świętym miejscem jest główną zasługą ob. Nuchyma Ormianera i Jakuba Pellera, przewodniczącego Powiatowego Komitetu Żydowskiego". W materiałach z 2019 r., znalezionych w sieci, widoczne są flagi izraelskie wetknięte w ogrodzenie.
} 
browskich Żydów. Następnie Zarząd Główny Związku Religijnego Wyznania Mojżeszowego zrzekł się prawa własności do nieruchomości na rzecz Skarbu Państwa i zastrzegł, że może być wykorzystana tylko do celów kulturowych bądź oświatowych. W kolejnych dekadach powstały plany adaptacji budynku, niektóre nawet wdrożono $\mathrm{w}$ początkowym etapie, ostatecznie $\mathrm{z}$ różnych powodów nie doszło do ich realizacji; $w$ tym czasie stan budynku systematycznie się pogarszał. W latach osiemdziesiątych z brakiem odzewu spotkała się propozycja krakowskiej gminy żydowskiej, by odnowić synagogę i zorganizować w jej wnętrzu muzeum poświęcone kulturze i historii Żydów. W 2006 r. decyzją wojewody małopolskiego Skarb Państwa przekazał budynek Gminie Dąbrowa Tarnowska. Pod presją Wojewody Małopolskiego budynek synagogi został odrestaurowany dzięki wsparciu funduszy europejskich ${ }^{40}$. Podniesiona z ruin synagoga, w której w 2012 r. zorganizowano Ośrodek Spotkania Kultur wraz z wystawą główną, była dobrą ilustracją tego, co John E. Tunbridge i Gregory J. Ashworth określili mianem "dziedzictwa nieuznawanego" ${ }^{41}$. W Dąbrowie duży wpływ na publiczną pamięć o lokalnych Żydach miał tragicznie zmarły dziennikarz Jerzy Rzeszuto, autor książki Żydzi dąbrowscy ${ }^{42}$. Książkę wskazywano jako podstawowe źródło informacji o historii i kulturze lokalnych Żydów, a Rzeszutę jako jednego z inicjatorów otwarcia Muzeum Judaistycznego (później Izby Pamięci) w jednym z pomieszczeń mieszkania, gdzie po wojnie żyła rodzina Rothów, religijnych Żydów, którzy ze względu na zły stan dąbrowskiej synagogi zorganizowali tam dom modlitwy. W pracy Rzeszuty dominowały dwa motywy: przekonanie o powszechnym ratowaniu Żydów przez społeczność lokalną oraz zrównanie doświadczeń wojennych Polaków i Żydów, co można traktować jako przejaw ówcześnie dominującego polskiego dyskursu pamięci o Żydach i Zagładzie. W rozdziale zatytułowanym „Eksterminacja Żydów Dąbrowskich. Holocaust” Rzeszuto pisał o wspólnym cierpieniu:

Stawiani przez okupanta pod jedną ścianą śmierci Polacy i Żydzi ginęli setkami i tysiącami, mordowani publicznie i potajemnie, w egzekucjach, w więzieniach, katowniach i różnego rodzaju obozach. Często ginęli Polacy za pomoc okazaną swym żydowskim sąsiadom, przyjaciołom, znajomym, a także nieznajomym, szukającym ratunku. Połączyły ich bezimienne groby [...] Okupacja hitlerowska niosła ze sobą eksterminację narodu polskiego oraz zagładę ludności żydowskiej zamieszkującej nasze ziemie ${ }^{43}$.

Dziennikarz powołał się na ustalenia regionalisty Józefa Kozaczki, który w czasie wojny pomógł dwóm siostrom Birnbaum-Windheil zdobyć aryjskie

${ }^{40}$ Ówczesny burmistrz przyznał w wywiadzie ze mną, że miasto próbowało się odwołać od tej decyzji. Wywiad został przeprowadzony w 2012 r. w Dąbrowie Tarnowskiej, R 37.

${ }^{41}$ Dissonant heritage, John E. Tunbridge, Gregory J. Ashworth, Dissonant Heritage: the Management of the Past as a Resource in Conflict, Chicester: Wiley, 1996.

${ }^{42}$ Jerzy Rzeszuto, Żydzi dąbrowscy, Dąbrowa Tarnowska: „Kurier Dąbrowski”, 1993.

${ }^{43}$ Ibidem, s. 187-188. 
dokumenty i wyjechać na roboty do Niemiec, gdzie przetrwały wojnę. Kozaczka był szefem dąbrowskiego Związku Bojowników o Wolność i Demokrację. W swoich publikacjach często odwoływał się do dwóch figur dyskursu o ratowaniu Żydów w PRL: antypolskości i niewdzięczności Żydów ${ }^{44}$. Rzeszuto, powołując się na ustalenia Kozaczki, zrównał liczbę 150 ocalałych dąbrowskich Żydów z liczbą uratowanych przez Polaków mieszkańców żydowskich. Powtórzył też za nim nieudokumentowaną tezę o zamordowanych z tego powodu 62 Polakach $^{45}$. Z tymi twierdzeniami polemizował Jan Grabowski ${ }^{46}$, zauważając, że m.in. przyjęta tam definicja pomocy była zbyt szeroka i obejmowała np. przypadek braku denuncjacji. Nie brała też pod uwagę wypadków zmiany postaw: od udzielania schronienia po zamordowanie ukrywanych. Co ważne, przywołane tezy Rzeszuty i Kozaczki znalazły się zarówno na wystawie stałej w odrestaurowanej synagodze, w materiałach informacyjnych, jak i w katalogu do spektaklu Teatru Nie Teraz, który przedstawię jako reprezentatywną praktykę pamięci dla dominującego dyskursu upamiętniania w Dąbrowie.

Wystawa stała ${ }^{47}$ paradoksalnie niewiele mówiła o żydowskiej historii i kulturze - w przedstawieniu tego dziedzictwa dominował ogólny plan oraz sprowadzenie go do wizerunku chasydzkich, ortodoksyjnych mężczyzn. Nieobecne były głosy mieszkańców żydowskich oraz konkretne losy, zastąpione zbiorową kategorią „,Żydzi”. Wystawa w połowie została poświęcona historii i kulturze nieżydowskich dąbrowian. Na przykład obok planszy o początkach gminy żydowskiej umieszczono tę dotyczącą historii parafii rzymskokatolickiej; w gablocie ustawionej w centrum sali modlitewnej odrestaurowanej synagogi umiejscowione zostały przedmioty związane z judaizmem, a w podstawie gabloty: zdjęcie z wnętrza dąbrowskiego kościoła parafialnego pw. Wszystkich Świętych ${ }^{48}$. Narrację o drugiej wojnie światowej zdominował wizerunek aktywnej postawy nieżydowskich mieszkańców w czasie okupacji. W jednej z gablot, która została opatrzona napisami po przeciwległych stronach: „terror” i „opór”, wyeksponowano szczątki alianckiego samolotu Halifax, który miał lecieć na pomoc biorącym udział w powstaniu warszawskim, a został zestrzelony przez Niemców

${ }^{44}$ Józef Kozaczka, Pomoc Żydom w powiecie Dąbrowa Tarnowska [w:] Polacy Żydzi 19391945, oprac. Stanisław Wroński i Maria Zwolakowa, Warszawa: Książka i Wiedza, 1971, s. 341-346.

${ }^{45}$ Rzeszuto, Żydzi dąbrowscy..., s. 198.

${ }^{46}$ Grabowski, Judenjagd. Polowanie na Żydów 1942-1945....

${ }^{47}$ Wystawę stałą poddałam analizie na podstawie własnej obserwacji z 2014 r. i zgromadzonych wtedy materiałów. Ponownie miałam okazję przyjrzeć się wystawie oraz posłuchać narracji dyrektora OSK w 2018 r. razem z grupą anglojęzycznych studentów uczestniczących w kursie prof. Marka Kuci.

${ }^{48}$ Po części wynikało to z przyjętej struktury organizacyjnej OSK. W jej ramach funkcjonuje Muzeum Powiśla Dąbrowskiego ze zbiorami związanymi z drugą wojną światową oraz codziennością dawnej wsi - i oba te tematy wkomponowane zostały w ekspozycję. 
w 1944 r. nad Dąbrową Tarnowską ${ }^{49}$. Figura aktywnej postawy Polaków została podtrzymana we fragmencie o niesieniu pomocy Żydom:

Pomimo najsurowszych konsekwencji, które groziły za jakąkolwiek pomoc i ukrywanie Żyda, niektórzy nie zlękli się i z poświęceniem nieśli pomoc. Angażowano do tego również polskich księży, którzy wystawiali Żydom fałszywe chrześcijańskie świadectwa chrztu. Wielu Dąbrowian przypłaciło swoją humanitarną postawę życiem. W ciągu zaledwie kilku tygodni 1942 r. za pomoc w ukrywaniu Żydów rozstrzelano w Dąbrowie i okolicy 62 osoby. Druga wojna światowa wystawiła na próbę relacje polsko-żydowskie, relację sąsiad Polak - sąsiad Żyd. Swoją postawą wielu mieszkańców Dąbrowy i okolic pokazało jednak niezłomność pewnych zasad i utrwaliło jeszcze mocniej związek pomiędzy obiema kulturami, które przynależały do siebie terytorialnie od tak długiego czasu ${ }^{50}$.

Według tej wizji - w sytuacji bycia blisko Zagłady - nieżydowscy dąbrowianie potwierdzili niezłomność charakterów, a nawet przyczynili się do poprawy stosunków polsko-żydowskich - w cytowanym tekście mowa przecież o utrwaleniu na skutek wojny związku między obiema kulturami. We fragmencie wystawy pojawiła się wzmianka o „polowaniach”, czyli obławach organizowanych przez Niemców po 1942 r. do końca wojny na ukrywających się Żydów przy licznym, podejmowanym z własnej inicjatywy udziale członków lokalnej społeczności ${ }^{51}$. Włączenie tej informacji zainspirowała zresztą dr Edyta Gawron, konsultantka merytoryczna wystawy, choć ostateczna treść musiała zostać zaakceptowana przez przedstawicieli władz samorządowych ${ }^{52}$. Stąd na wystawie brakowało wyjaśnienia, czym były „polowania”, i wyraźnego wskazania, że uczestniczyli w nich Polacy. Doświadczenia mieszkańców żydowskich w czasie wojny nie zostały nazwane „Zagładą” bądź „Holokaustem”. W konsekwencji nie uwzględniono odrębnego charakteru tych doświadczeń, diametralnie odmiennych od przeżyć nieżydowskich mieszkańców w czasie wojny. Dyrektor Ośrodka Spotkań Kultur Paweł Chojnowski w audycji Skarby Małopolski w grudniu 2019 r. tłumaczył: „Zarzuca się nam czasem, że na naszej wystawie nie eksponujemy historii Holokaustu. Ja odpowiadam tak: to nie jest muzeum Holokaustu. To nie to miejsce. Tutaj bardziej skupiamy się na tym, co może nas łączyć" 53 .

\footnotetext{
${ }^{49}$ Wiele praktyk upamiętniających Ośrodka Spotkania Kultur dotyczyło tego wydarzenia, m.in. „Gra terenowa z Dąbrowskim Halifaksem” zorganizowana we wrześniu 2020 r.

${ }^{50}$ Wystawa stała w OSK w Dąbrowie Tarnowskiej.

${ }^{51}$ Jan Grabowski, Judenjagd. Polowanie na Żydów...

${ }^{52}$ Wywiad przeprowadzony przez MDD w sierpniu 2012 r., R 58.

${ }^{53}$ Podczas audycji dyrektor OSK deklarował, że muzeum jest przestrzenią do mierzenia się z trudnymi zagadnieniami relacji polsko-żydowskich i odwołał się do kolekcji mundurów wykorzystywanej w trakcie lekcji muzealnych. Przyznał, że w Wojsku Polskim walczyło wielu Żydów. Odwołał się do powojennych represji, które spotykały członków Armii Krajowej z rąk Urzędu Bezpieczeństwa i dodał: „mówimy, że bardzo często Urząd Bezpieczeństwa był zasilany przez lewicowych polskich Żydów". Pomijając przywołanie stereotypu żydokomuny, muzealnik
} 


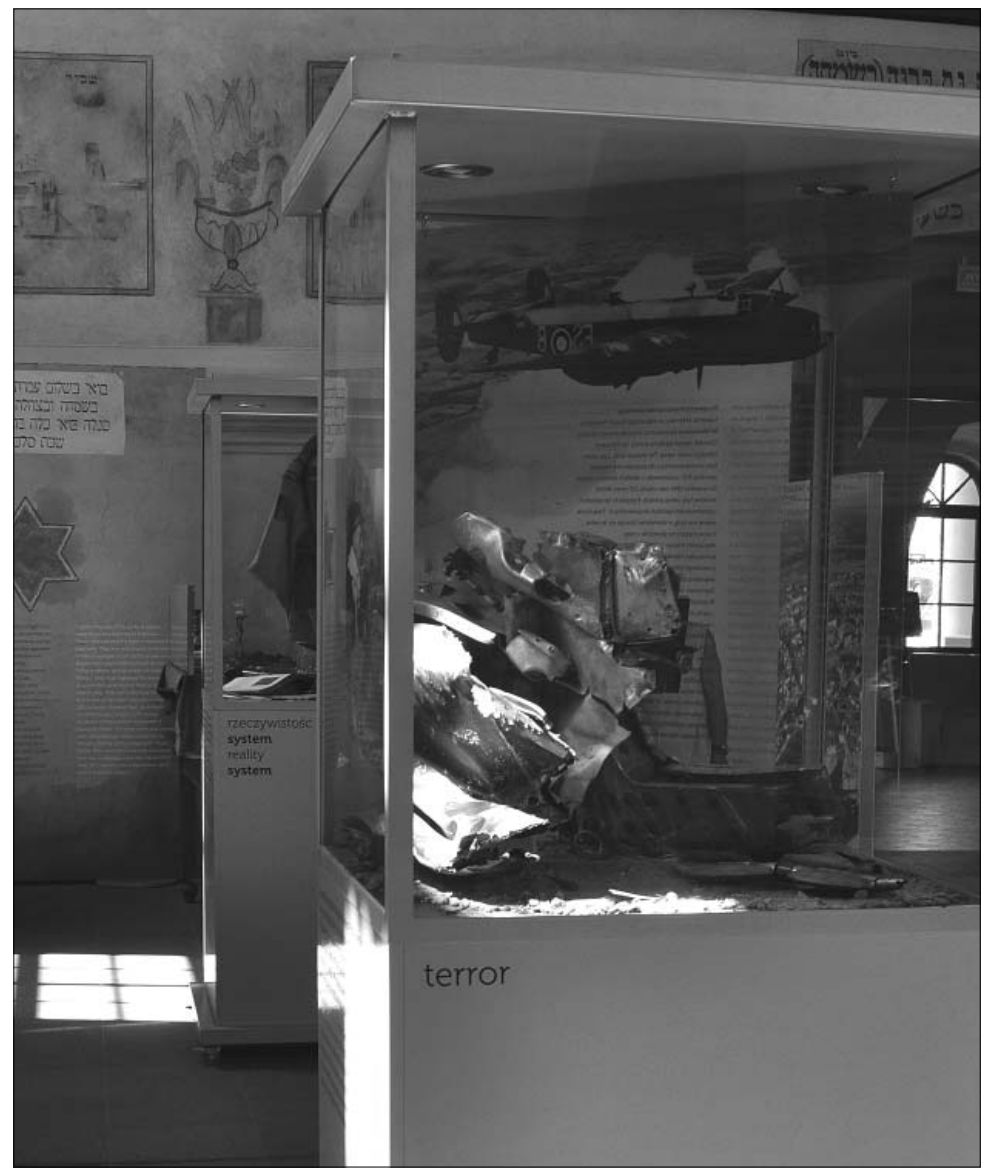

Fragment wystawy stałej wewnątrz synagogi w Dąrowie Tarnowskiej. Na zdjęciu na pierwszym planie widoczne sq szczątki alianckiego samolotu Halifax zestrzelonego przez Niemców w 1944 r. nad Dąbrowq Tarnowskq. Zdjęcie wykonane w 2012 r. (fot. Marta Duch-Dyngosz)

Praktyką pamięci, dobrze ilustrującą upamiętnianie w Dąbrowie Tarnowskiej było wystawienie w synagodze 30 czerwca i 1 lipca 2013 r. sztuki Romana Brandstaettera Dzień gniewu. Teatr Nie Teraz na czas spektaklu umieścił w sali modlitw drewnianą scenę w kształcie krzyża. Brak wrażliwości wobec żydowskiego wymiaru tego miejsca potwierdziła przedstawiona w katalogu do spek-

nie podał przykładu trudnej pamięci dotyczących postaw nieżydowskich mieszkańców. Zob. http://www.radiokrakow.pl/audycje/skarby-malopolski/synagoga-w-dabrowie-tarnowskiejarchitektoniczna-perla-chasydyzmu/?fbclid=IwAR3nj6sacNkKOtGw2OlsMJVVcD3NEEkRiH93 dWjxhGN1K2cKIP7uFCTtD0Q/ (dostęp 6 VI 2021 r.). 
taklu misja teatru, w którym reżyser, dyrektor teatru Tomasz A. Żak przedstawił powody wystawienia sztuki:

Pojawił się gniew - efekt terroru poprawności politycznej, która rujnuje prawdę historyczną, ale również efekt uświadomienia sobie antypolskich konsekwencji coraz częstszego upubliczniania haniebnych przesłań o „polskich obozach koncentracyjnych”, czy o „wyssanym z mlekiem matki antysemityzmie". [...] Praca nad tekstem urodzonego w Tarnowie Żyda, polskiego patrioty i katolika, znawcy Biblii, pisarza i człowieka teatru, zderzyła nas z wyjątkową wiedzą o czasach „drugiej Apokalipsy” i z wyjątkową tejże wiedzy dramaturgiczną metaforą. Uświadomiła nam prawdę dzisiaj zapoznaną o tym, że ten, kto nie jest z Chrystusem, jest z szatanem. A odwołując się do treści Dnia gniewu, należy ufać stwierdzeniu, że „wiara czyni cuda”, ale też pamiętać, że chodzi o wiarę w Chrystusa cierpiącego, ukrzyżowanego i zmartwychwstałego ${ }^{54}$.

Po spektaklu w krótkim przemówieniu burmistrz podkreślił: „[...] tu specjalnie nie było jakiś ekscesów. Tu była dobra współpraca. Nie było jakieś dyskryminacji i myślę, że na ten temat mówią nasze wystawy".

Upamiętnianie Zagłady w Dąbrowie Tarnowskiej charakteryzowała strategia „nieobecności”, o której pisał Dominick LaCapra, obrazująca traumatyczne wydarzenie jako coś abstrakcyjnego, niemającego swojego początku ani końca, co jest przeciwieństwem historycznej precyzji stosowanej w strategii „straty" 55 . Dąbrowskie upamiętnianie było najwyraźniejszym spośród trzech przypadków przejawem nadużycia pamięci.

\section{Włączenie i uznanie pamięci żydowskiej}

W przypadku Rymanowa na tle omówionych praktyk pamięci wyróżniły się oddolne działania podejmowane przez Stowarzyszenie na rzecz Ochrony Dziedzictwa Kulturowego Ziemi Rymanowskiej „Spotkanie Rymanów”, przede wszystkim organizowane od $2008 \mathrm{r}^{56}$ Dni Pamięci o Żydowskiej Społeczności Rymanowa. W reportażu filmowym Andrzeja Potockiego Miasteczko Rymanów,

\footnotetext{
${ }^{54}$ Katalog do spektaklu Dzień gniewu Teatru Nie Teraz.

${ }^{55}$ Absence, loss zob. Dominick LaCapra, Writing History, Writing Trauma, Baltimore: The Johns Hopkins University Press, 2001.

${ }^{56}$ Więcej o praktykach upamiętniających Holokaust organizowanych na Podkarpaciu głównie w ramach Międzynarodowego Dnia Pamięci o Ofiarach Holokaustu - zob. Magdalena Prokopowicz, Wacław Wierzbieniec, Pamięć o Holokauście na Podkarpaciu na poczq̨tku XXI wieku na przykładzie obchodów rocznicowych, „Studia Podlaskie” 2016, nr 24, s. 189-218. Wśród praktyk upamiętniających autorzy opisują inicjatywy organizowane w Rymanowie (s. 202-205), zauważając, że „[...] nie są wolne od trudnych tematów i negatywnych emocji, które wywołują w uczestnikach uroczystości" (s. 205). Prokopowicz i Wierzbieniec przeprowadzili analizę treści artykułów prasowych w lokalnych mediach, materiałów informacyjnych oraz treści zamieszczonych na wybranych stronach internetowych.
} 
„mein stetełe Rymanow” z 2010 r. jeden z pomysłodawców stowarzyszenia, wyjaśniając motywy podejmowanych praktyk, zauważył fenomen rozdwojenia pamięci - publicznego zapominania i milczenia, przy jednoczesnym wspominaniu, przywoływaniu Żydów w przekazie potocznym:

Nie można zapomnieć o ludziach, którzy żyli tutaj i którzy nie są w żaden sposób upamiętnieni, którzy bardzo silnie tkwią w pamięci [...] każdego pojedynczego rymanowianina. Natomiast jakby z publicznej pamięci zostali wyparci całkowicie. Chcieliśmy to przywrócić i stąd pomysł organizacji Dni Pamięci o Żydowskiej Społeczności Rymanowa.

Ważnym etapem $\mathrm{w}$ przywoływaniu dziedzictwa żydowskiego były prace dziennikarza TVP Rzeszów Andrzeja Potockiego, szczególnie książka pt. Żydzi rymanowscy ${ }^{57}$. Autor skupił w niej uwagę na szczegółach historycznych, przywołał konkretne postaci, dostrzegł różnorodność społeczności żydowskich. Gdy prowadziłam badania terenowe, książka była jeszcze dostępna w miejscowej księgarni oraz w informacji turystycznej w pobliskiej miejscowości uzdrowiskowej, Rymanowie-Zdroju. Potocki opowiedział, że z propozycją napisania monografii zwrócił się do niego Josef Rottenberg, rymanowski ocalały (po wojnie używał nazwiska Rotem). To dzięki niemu w monografii znalazły się przetłumaczone z języka angielskiego fragmenty Księgi pamięci Rymanowa oraz korespondencji Potockiego z ocalałymi mieszkańcami żydowskimi. Dziennikarz przyznał, że sposób, w jaki przedstawił Zagładę, w tym postawy nieżydowskich mieszkańców, stał się źródłem konfliktu z niektórymi rymanowskimi Żydami, o czym autor napisał kilkakrotnie w książce. Największe zarzuty miał Rotem, a dyskusja między nim a autorem odbyła się nawet na łamach lokalnego miesięcznika „Nasz Rymanów"58. Dotyczyła przede wszystkim oceny postaw mieszkańców nieżydowskich, kwestii przejęcia przez rymanowian żydowskiego majątku, także działalności Judenratu i Żydowskiej Służby Porządkowej. Z jednej strony trzeba przyznać, że Potocki opisał przypadki negatywnych postaw - mordowania, wydawania, współpracy z Niemcami - podając inicjały nazwisk sprawców, co uzasadnił w książce:

[...] znam te nazwiska, znają je także Żydzi rymanowscy, którzy ocaleli z Holocaustu, zna je zapewne część obecnych mieszkańców Rymanowa. Ci ludzie już nie żyją, a ich potomni nie powinni być napiętnowani haniebnymi czynami swoich przodków ${ }^{59}$.

${ }^{57}$ Andrzej Potocki, Żydzi rymanowscy, Krosno: Oficyna Wydawnicza Apla, 2000.

${ }^{58}$ Zob. Josef Rotem, List do Stefana Szymskiego. O „Żydach rymanowskich”, ,Nasz Rymanów” 2001, nr 4, s. 6-7; Andrzej Potocki, Żydzi rymanowscy, „Nasz Rymanów” 2002 nr 8 (19), s. 8.

${ }^{59}$ Ibidem, s. 86. W wywiadach narracyjnych zrealizowanych z najstarszymi mieszkańcami Rymanowa i okolicznych miejscowości w 2018 i 2019 r. w ramach projektu „Społeczna antropologia pustki..." padały często nazwiska sprawców sądzonych po wojnie za zamordowanie ukrywanych żydowskich mężczyzn. Na łamach książki Potockiego również można odnaleźć wskazówki co do ich personaliów. 
Jednocześnie uznał za „wielce subiektywny i niesprawiedliwy [...] osąd” ocalałych zamieszczony w Księdze pamięci na temat „okrutnej postawy ludności nieżydowskiej w czasie Zagłady"60. Potocki wskazał za to sprawców wśród Żydów, posługując się kategorią zbiorową i pisząc o Judenracie czy o Żydowskiej Służbie Porządkowej bez uwzględnienia przymuszającego charakteru okoliczności, w jakich się znaleźli, oraz tego, jak odmienna była ich sytuacja w porównaniu do nieżydowskich mieszkańców.

Inną strategię przyjęli aktorzy społeczni zaangażowani w Dni Pamięci - zrobili miejsce dla wyrażenia doświadczeń i związanych z nimi emocji ocalałym i ich potomkom, nie cenzurując, nie oceniając, podejmując rozmowę. Udział rymanowskich Żydów i ich potomków w Dniach Pamięci stanowił jedno z głównych założeń tych oddolnych praktyk upamiętniających. Potomkowie rymanowskich ocalałych stali się jednymi z najważniejszych liderów pamięci w Rymanowie. Praktyką pamięci, która dobrze reprezentowała rymanowskie inicjatywy upamiętniające, był Marsz Pamięci. Co roku przebiegał on trasą, którą 13 sierpnia 1942 r. zgromadzeni w rymanowskim getcie Żydzi zostali zmuszeni przejść z rynku do oddalonej o kilka kilometrów stacji kolejowej we Wróbliku Szlacheckim. Mimo że uroczystości składały się z inicjatyw wychodzących poza tematykę zagłady rymanowskich Żydów, to rocznicę likwidacji getta organizatorzy wskazali jako z ich perspektywy najważniejszą. Język upamiętniania włączał żydowskich mieszkańców do wspólnoty obywateli i mieszkańców. Marsz, osadzony w przestrzeni fizycznej, angażował ciała uczestników, umożliwiając im zbudowanie empatycznej relacji z przeszłością. Pokazywał, że Zagłada wydarzyła się w konkretnym miejscu i czasie. Duża część mieszkańców, jak wynikało z wywiadów, miała świadomość, jakie wydarzenie Marsz upamiętnia. Pokonywanie kilkukilometrowego dystansu sprzyjało rozmowom i poznawaniu się uczestników - Żydów i nie-Żydów. Była to praktyka kameralna. Uczestniczyli w niej głównie osoby związane z Dniami Pamięci: organizatorzy, ich rodziny, zaproszeni goście i nieliczni rymanowscy mieszkańcy. Marsz przyciągał często uwagę badaczy społecznych spoza Polski zainteresowanych fenomenem upamiętniania społeczności żydowskich. Na stacji we Wróbliku praktykę kończyły krótkie przemówienia, złożenie kwiatów przy torach i odmówienie modlitwy kadisz. W przemówieniach organizatorzy konfrontowali uczestników z tym, co wydarzyło się w danej przestrzeni:

Mamy świadectwa, które twierdzą, że pociąg stał dwa, trzy dni na tej stacji. Później jeszcze stał dość długo przed Bełżcem. Prawdopodobnie duża część ludzi, którzy byli w wagonach, nie dojechali żywi do Bełżca. [...] Stańmy jeszcze przez chwilę $w$ milczeniu na miejscu, gdzie siedemdziesiąt lat temu kilkuset mieszkańców po raz ostatni byli jeszcze w Rymanowie... Pociąg odszedł w tamtą stronę ${ }^{61}$.

\footnotetext{
${ }^{60}$ Ibidem, s. 93.

${ }^{61}$ Fragment przemówienia Michała Lorenza podczas Marszu Pamięci w 2012 r.
} 


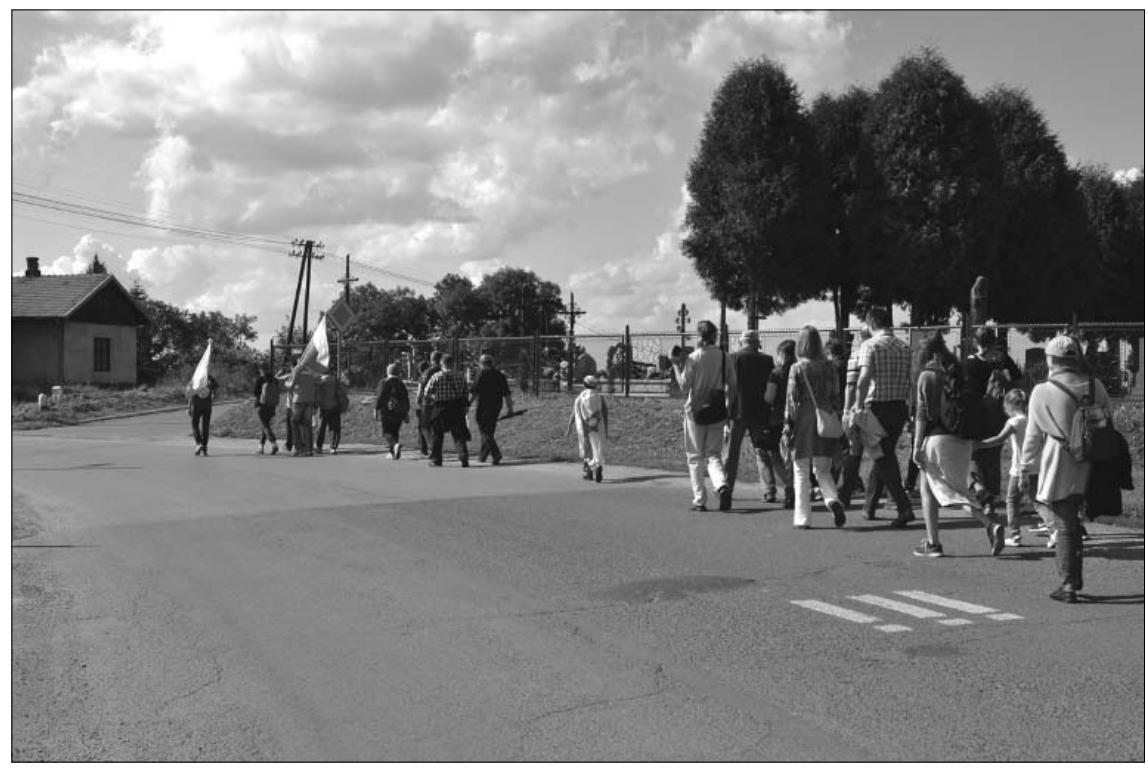

Uczestnicy Marszu Pamięci w 2014 r., który miał wówczas odwrotny kierunek: z Wróblika Szlacheckiego do Rymanowa, co miało symbolizować powrót Żydów do tej miejscowości (fot. Marta Duch-Dyngosz)

Zwykle w pewnej odległości od zgromadzonych stali przypatrujący się uroczystości mieszkańcy Wróblika.

Możliwość wyrażenia się perspektywy żydowskiej - od momentu, gdy powstawał program, przez uczestniczenie w inicjatywach, po przywoływanie żydowskich źródeł w lokalnej przestrzeni - była też tym czynnikiem, który pozwala scharakteryzować upamiętnienie jako odwołujące się do krytycznego dyskursu pamięci. Przychodzi na myśl wspomniana wcześniej strategia „straty”, która zakłada odwołanie się do historycznego szczegółu ${ }^{62}$. Koncepcja ta pokazuje, że walka z jakimikolwiek formami uprzedzeń, w tym z antysemityzmem, zaczyna się od wskazania konkretnych przykładów ich wystąpienia w przeszłości. W Rymanowie strategia ta najwyraźniej ujawniła się na poziomie nieformalnych relacji między uczestnikami trwających kilka dni uroczystości. Jednocześnie inni aktorzy społeczni coraz wyraźniej odwoływali się w swoich praktykach do krytycznej perspektywy. Na przykład w 2014 r. miejscowy proboszcz doprowadził do odsłonięcia w przedsionku rymanowskiego kościoła tablicy upamiętniającej zamordowanych Marię Bolanowską, jej syna Piotra oraz ukrywanego przez nich Ajzika Bobika. Ich historia wiąże się z jednym z lokalnych mieszkańców, który zauważył przechodzącego przez pola Ajzika i doniósł o nim Niemcom. Wszyscy

${ }^{62}$ LaCapra, Writing History..., s. 64. 
troje zostali zamordowani i pochowani najprawdopodobniej na cmentarzu jeńców radzieckich w miejscu, gdzie do dziś stoi krzyż. Przez długi czas rymanowski ocalały Josef Rottenberg zabiegał o uczczenie tego miejsca i pamięci o zamordowanych. Na mszę św. poświęconą zabitym rymanowianom prawie nikt jednak nie przyszedł. Innym przykładem inicjatywy, która miała potencjał konfrontowania mieszkańców z pamięcią o negatywnych postawach nieżydowskich rymanowian, była projekcja filmu dokumentalnego w reżyserii Marii Zmarz-Koczanowicz Była wojna. Reżyserka jest związana z okolicami Rymanowa przez swojego ojca, którego rodzina od czasów przedwojennych miała wakacyjny dom w Rymanowie-Zdroju. W dokumencie przeplatają się rozmowy dwudziestokilkuletniego syna Zmarz-Koczanowicz prowadzone ze starszymi mieszkańcami miasta z dyskusjami na temat pamięci lokalnej, które toczą młodzi ludzie, przyjaciele syna towarzyszący mu w zbieraniu informacji. W filmie pojawia się scena, gdy w kościele, po próbie chóru, starsi mieszkańcy rozmawiają o wojnie. Niektórzy zaczynają mówić $\mathrm{w}$ charakterystyczny dla pamięci potocznej sposób:

A: A jeszcze proszę nam [...] opowiedzieć o rodzinie Feikielów, którzy na Gąsiorówkach tak marnie poszli, a synowie mali schowali się w takiej...

B: ...jeden się schował, trzynastoletni.

A: Trzech...

B: W nocy... napad, co oni tam mieli, to nie wiem. W każdym bądź razie efekt był taki: zastrzelili matkę, ojca i jednego z dzieci, a jeden uciekł przez okno, trzynastoletni.

C: ...i podpalili dom.

B: I podpalili dom. I się spaliło razem. No.

A: I nie wiadomo, dlaczego.

B: To było za Niemca...

A: Oni byli bogaci, mieli pieniądze, majątek.

C: Dlaczego nikt nie wie do dziś?

B: Co?

A: Tajemnica. Nie wiadomo.

B: [śmiech] Tajemnica poliszynela. Wszystko się wiedziało kto... Do dziś się wie $^{63}$.

Film wzbudził wśród publiczności wiele kontrowersji. Wyzwolił jednak refleksję na temat grupy własnej. Lokalna dziennikarka i nauczycielka zorganizowała po raz drugi w Rymanowie projekcję filmu. W rozmowie ze mną liderka pamięci zastanawiała się:

[...] to nie jest tak, że reżyser pokazał w złym świetle Rymanów. To ci ludzie opowiedzieli o tej historii, ja myślę, że one tak głęboko w nich tkwiły, że nie zostały rozliczone, że nie zostały wyjaśnione, że po tylu latach, oni nagle, siedząc w kościele, bo to akurat było po próbie chóru w kościele, zaczęli o nich

${ }^{63}$ Fragment filmu dokumentalnego Była wojna w reżyserii Marii Zmarz-Koczanowicz, Studio Largo, 2013. 
mówić, być może to spowodował kościól, być może atmosfera, być może chcieli o tym powiedzieć, ale myślę, że to ich gnębiło $[. . .]^{64}$.

Trwałość i regularność praktyk związanych z historią i kulturą społeczności żydowskiej zapewniło otwarcie w 2014 r. Domu Żydowskiego w Rymanowie. Rodzina jednej z liderek pamięci rymanowskiego upamiętniania - Malki Shacham Doron, obywatelki Izraela, od pewnego czasu również Polski, należącej do drugiego pokolenia Żydów po Zagładzie, kilka lat temu odkupiła kamienicę, która przed wojną należała do dziadków Doron. Do odrzwi została przybita mezuza. Kamienica zaczęła służyć Doron i jej rodzinie w czasie ich pobytów w Rymanowie. Jednocześnie parter budynku był udostępniany podczas wydarzeń związanych ze społecznością żydowską. Ich przykładem są obchody Międzynarodowego Dnia Pamięci o Ofiarach Holokaustu, któremu towarzyszy w województwie podkarpackim bogaty program wydarzeń w wielu miejscowościach. W 2019 r. dziennikarz Andrzej Potocki wygłosił wykład przybliżający sylwetkę Izydora Izaaka Rabiego, laureata Nagrody Nobla w dziedzinie fizyki, który wyemigrował z rodziną z Rymanowa jako kilkuletni chłopczyk na początku XX w. Postaci Rabiego poświęcone zostały Dni Pamięci, które odbyły się tego samego roku i kiedy do Rymanowa przyjechali potomkowie Rabiego. W ostatnich latach w Rymanowie można zaobserwować zmianę $\mathrm{w}$ konfiguracji zaangażowanych w upamiętnianie aktorów społecznych, wśród których centralną rolę wciąż odgrywała Doron, próbująca oprzeć swoje działania w dużym stopniu na lokalnych liderach.

\section{Podsumowanie}

W składających się na upamiętnienie praktykach i produktach pamięci wyraźnie przejawia się zróżnicowane wzajemne oddziaływanie między działającymi aktorami społecznymi a warunkami strukturalnymi. W przywołanych przypadkach liderzy upamiętnienia różnili się między sobą rozumieniem i stosunkiem do żydowskiego dziedzictwa, stopniem otwarcia się na perspektywę innej pamięci oraz świadomością istnienia obszarów trudnej pamięci. W większym bądź mniejszym stopniu wychodzili w swoich inicjatywach poza reguły i zasady pamiętania obowiązujące daną wspólnotę pamięci. Byli wśród nich tacy, którzy działając na rzecz włączenia wielowiekowej obecności Żydów w historię miasta, czynili to na określonych warunkach, stawiając granice krytycznej perspektywie. Liderzy, przewidując reakcję społeczności, mogli cenzurować własne działania, zmieniać ich zakres, wycofywać się. Ich działanie przybierało różne formy: „od podporządkowania się, przez unikanie i działanie strategiczne, po R 54 .

${ }^{64}$ Wywiad przeprowadzony przez Martę Duch-Dyngosz w czerwcu 2015 r. w Rymanowie, 
działalność wywrotową"65. Sprawstwo liderów pozostawało zróżnicowane, zależąc też od „emergentnych własności osobistych” - „od osobistych trosk i stopnia zaangażowania podmiotów działania, od kosztów, jakie poniosą w celu zrealizowania swoich projektów w obliczu strukturalnych przeszkód i utrudnień. W podobny sposób wynik ten zależy od gotowości podmiotów działania do skorzystania z możliwości"66. Jednocześnie reakcja pozostałych członków wspólnoty pamięci ma wpływ na to, jak przebiegnie dalej proces włączania do dyskursu publicznego tego, co przemilczane. Wszystkie przypadki łączy to, że podjęte inicjatywy pozwoliły wypracować przez lokalną społeczność sposoby radzenia sobie z pewną „sytuacją krytyczną" ${ }^{\text {", }}$, związaną z demokratyzowaniem się pamięci w Polsce. Coraz większe zainteresowanie dziedzictwem kulturowym, możliwość restytucji cmentarzy i synagog, pojawienie się w sferze publicznej tematów objętych do tej pory społecznym tabu sprawiło, że dotychczasowa rutyna wobec historii i kultury lokalnych Żydów przestała działać. Z możliwości tych skorzystali liderzy, którzy podjęli negocjacje ze wspólnotą, wybierając ten sposób upamiętniania, który w ich przekonaniu miał szansę trafić do członków wspólnoty, zmienić status quo. Przy czym perspektywa działających podmiotów była jak zwykle niekompletna i w trakcie ulegająca przeobrażeniom. Jak przyznał jeden z liderów rymanowskiego upamiętniania, jeśli chodzi o zmianę świadomości społecznej, to o katharsis, jak określił upragniony efekt swoich działań, można było mówić w przypadku nielicznej grupy mieszkańców Rymanowa. Na upamiętnianie należy popatrzeć zatem jak na długi proces, gdzie widać ciągłe napięcie między przepracowywaniem a nadużywaniem pamięci. W ostatnim czasie w omawianych miejscowościach doszło do potencjalnie przełomowych dla dalszego upamiętniania wydarzeń. W 2020 r. w Bobowej lokalny przedsiębiorca otworzył w 2020 r. izbę pamięci poświęconą bobowskiej społeczności żydowskiej. Muzeum zlokalizował w dawnym żydowskim domu, stojącym tuż przy rynku. Ekspozycję pt. „Okruchy pamięci” utworzyły przede wszystkim przedmioty należące niegdyś do Żydów, kolekcjonowane przez przedsiębiorcę. Izbę nazwał „Domem Landaua”, spełniając prośbę potomków dawnych właścicieli. Zapoczątkował w ten sposób oddolne upamiętnienie, które odchodzi od abstrakcyjnego obrazowania dziedzictwa żydowskiego. W Dąbrowie Tarnowskiej w 2019 r. została otwarta w podziemiach Ośrodka Spotkania Kultur koszerna kawiarnia, na odrzwiach której przytwierdzona została mezuza, podkreślająca żydowski charakter budynku. W Rymanowie natomiast dalsze kierunki upamiętnienia poróżniły zaangażowanych w nie do tej pory liderów pamięci, przy czym jedną z głównych osi konfliktu stało się pytanie o to, kto ma większe prawo do dziedzictwa żydowskiego - potomkowie lokalnych Żydów czy nieżydowskich

${ }^{65}$ Margaret S. Archer, Człowieczeństwo. Problem sprawstwa, tłum. Agata Dziuban, Zakład Wydawniczy Nomos, Kraków, 2013, s. 23.

${ }^{66}$ Ibidem, s. 23.

${ }^{67}$ Giddens, Stawanie się..., s. 102. 
mieszkańców. W kontekście wszystkich przypadków warunkiem strukturalnym o ogromnym znaczeniu stała się polityka historyczna kształtowana przez obóz rządzący od 2015 r. Te wszystkie czynniki zachęcają, by dokonać dalszej analizy strategii dyskursywnych upamiętnień ostatnich lat.

\section{BIBLIOGRAFIA}

Adorno Theodor W., What Does Coming to Terms with the Past Mean?, tłum. Timothy Bahti i Geoffrey Hartman [w:] Bitburg in Moral and Political Perspective, red. Geoffrey H. Hartman, Bloomington: Indiana University Press, 1986.

Archer Margaret. S., Człowieczeństwo. Problem sprawstwa, tłum. Agata Dziuban, Kraków: Zakład Wydawniczy Nomos, 2013.

Archer Margaret S., Morphogenesis versus Structuration. On Combining Structure and Action, „The British Journal of Sociology” 1982, nr 33 (4).

Bauman Zygmunt, Allosemitism: Premodern, Modern, Postmodern [w:] Modernity, Culture, and 'the Jew', red. Bryan Cheyette, Laura Marcus, Stanford: Stanford University Press, 1998.

Bauman Zygmunt, Nowoczesność i Zagłada, tłum. Tomasz Kunz, Kraków: Wydawnictwo Literackie, 2009, wersja Kindle.

Bellah Robert N., Madsen Richard, Sullivan William M., Swidler Ann i Tipton Steven M., Habits of the Heart. Individualism and Commitment in American Life, Berkeley: University of California Press, 1985.

Cała Alina, Wizerunek Żyda w polskiej kulturze ludowej, Warszawa: Oficyna Naukowa, 2005. Connerton Paul, Jak społeczeństwa pamiętaja, tłum. Marcin Napiórkowski, Warszawa: Wydawnictwa Uniwersytetu Warszawskiego, 2012.

Connerton Paul, Seven Types of Forgetting, „Memory Studies” 2008, nr 1 (1).

Giddens Anthony, Stanowienie społeczeństwa. Zarys teorii strukturacji, tłum. Stefan Amsterdamski, Poznań: Zysk i S-ka, 2003.

Giesen Bernard, Triumph and Trauma, Boulder: Paradigm Publishers, 2004.

Grabowski Jan, Judenjagd. Polowanie na Żydów 1942-1945. Studium dziejów pewnego powiatu, Warszawa: Stowarzyszenie Centrum Badań nad Zagładą Żydów, 2011.

Janicka Elżbieta, Żukowski Tomasz, Przemoc filosemicka? Nowe polskie narracje o Żydach po roku 2000, Warszawa: Instytut Badań Literackich PAN, 2016.

Kłoskowska Antonina, Polacy wobec zagłady Żydów polskich. Próba typologii postaw, „Kultura i Społeczeństwo” 1988, nr 4.

Kucia Marek, Duch-Dyngosz Marta i Magierowski Mateusz, Anti-Semitism in Poland. Survey Results and a Qualitative Study of Catholic Communities, „Nationalities Papers” 2013, nr 42 (1).

LaCapra Dominick, Writing History, Writing Trauma, Baltimore: The Johns Hopkins University Press, 2001.

Leder Andrzej, Prześniona rewolucja. Ćwiczenie z logiki historycznej, Warszawa: Wydawnictwo Krytyki Politycznej, 2014.

Malicki Krzysztof, Poza wspólnota pamięci. Życie i Zagłada Żydów w pamięci mieszkańców regionu podkarpackiego, Warszawa: Wydawnictwo IFiS PAN, 2017.

Meng Michael, Shattered Spaces: Encountering Jewish Ruins in Postwar Germany and Poland, Cambridge, MA: Harvard University Press, 2011.

Michlic Joanna B., Obcy jako zagrożenie. Obraz Żyda w Polsce od roku 1880 do czasów obecnych, tłum. Anna Switzer, Warszawa: Żydowski Instytut Historyczny, 2015. 
Michlic Joanna B., Piętno Zagłady. Wojenna i powojenna historia oraz pamięć żydowskich dzieci ocalałych $w$ Polsce, tłum. Adam Musiał, Warszawa: Żydowski Instytut Historyczny, 2020.

Nowak Jacek, Kapralski Sławomir i Niedźwiedzki Dariusz, On the Banality of Forgetting. Tracing the Memory of Jewish Culture in Poland, Berlin: Peter Lang, 2018.

Prokopowicz Magdalena, Wierzbieniec Wacław, Pamięć o Holokauście na Podkarpaciu na początku XXI wieku na przykładzie obchodów rocznicowych, „Studia Podlaskie” 2016, nr 24.

Rączy Elżbieta, Sytuacja Żydów w powiecie gorlickim w okresie okupacji niemieckiej [w:] Dzieje społeczności żydowskiej powiatu gorlickiego podczas okupacji niemieckiej 1939-1945, red. Michał Kalisz, Elżbieta Rączy, Rzeszów: Instytut Pamięci Narodowej, 2015.

Ricoeur Paul, Pamięć, historia, zapomnienie, tłum. Janusz Margański, Kraków: Universitas, 2012.

Rydgren Jens, The Power of the Past. A Contribution to a Cognitive Sociology of Ethnic Conflict, „Sociological Theory” 2007, nr 25 (3).

Tokarska-Bakir Joanna, How to Exit the Conspiracy of Silence? Social Sciences Facing the Polish-Jewish Relations, „East European Politics \& Societies” 2011, nr 25.

Tokarska-Bakir Joanna, Legendy o krwi. Antropologia przesądu, Warszawa: W.A.B., 2008.

Tunbridge John E., Ashworth Gregory J., Dissonant Heritage: the Management of the Past as a Resource in Conflict, Chicester: Wiley, 1996.

Vinitzky-Seroussi Vered, Tegger Chana, Unpacking the Unspoken. Silence in Collective Memory and Forgetting, „Social Forces” 2010, nr 88 (3).

Zerubavel Eviatar, The Elephant in the Room. Silence and Denial in Everyday Life, New York: Oxford University Press, 2006.

\section{Analizowane materiały}

Kowalska Barbara, Z historii bobowskich Żydów, „Nasza Bobowska Gmina” 2013.

Kozaczka Józef, Pomoc Żydom w powiecie Dq̨browa Tarnowska [w:] Polacy Żydzi 1939-1945, oprac. Stanisław Wroński i Maria Zwolakowa, Warszawa: Książka i Wiedza, 1971.

Andrzej Potocki, Miasteczko Rymanów, mein stetele Rymanów, Telewizja Polska, 2010.

Potocki Andrzej, Żydzi rymanowscy, „Nasz Rymanów” 2002 nr 8 (19).

Potocki Andrzej, Żydzi rymanowscy, Krosno: Oficyna Wydawnicza Apla, 2000.

Rotem Josef, List do Stefana Szymskiego. O „Żydach rymanowskich”, „Nasz Rymanów”, 2001 nr 4.

Rzeszuto Jerzy, Żydzi dąbrowscy, Dąbrowa Tarnowska: „Kurier Dąbrowski”, 1993.

Zmarz-Koczanowicz Maria, Była wojna, Studio Largo, 2013.

\section{Analizowane praktyki pamięci}

Dni Bobowej z Kulturą Żydowską, Jak cadyk z Bobowej córkę wydawał, 8-9 VI 2013 r.

Dni Bobowej z Kulturą Żydowską „Szalom”, 21 VI 2014 r.

Dni Bobowej z Kulturą Żydowską „Szalom 2015”, 7 VI 2015 r.

V Dni Pamięci o Żydowskiej Społeczności Rymanowa, 8-10 VIII 2012 r.

VI Dni Pamięci o Żydowskiej Społeczności Rymanowa, 15-18 VIII 2014 r.

VII Dni Pamięci o Żydowskiej Społeczności Rymanowa, 12-4 VIII 2015 r.

Powiatowe obchody XI Dnia Pamięci o Holokauście i Przeciwdziałaniu Zbrodniom Przeciwko Ludzkości „Nie masz już w Polsce żydowskich miasteczek”, 19 IV 2013 r.

Spektakl Teatru Nie Teraz pt. Dzień gniewu Romana Brandstaettera, 30 VI 2013 r. w Ośrodku Spotkania Kultur w Dąbrowie Tarnowskiej. 